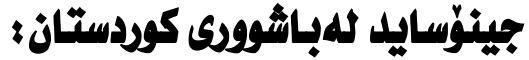

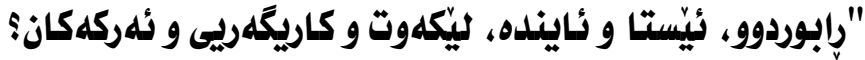

تلهها سليّمان

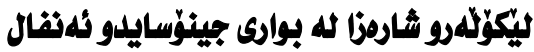

\section{بلدرجاو بوونى}

جينوّسايديكردنى كَلى كوردستان و كورد، لهباشوورى كوردستان "عيّراق" جِهندين ويّستكهى جوّراوجوَّى بهخوّوه بينيوه، بهعس وهك يارتى فهرمانرهواى عيّراق له سالّى 1963 تا 2003 گهورهترين بهريرسياريّتى

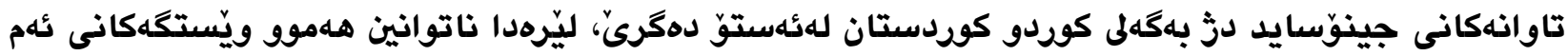
كردهيهو تكواوى وردهكارى و لايهنه جياجياكانى روون بكهينهوه، بهلّكو هـولْدهدهين كوّمهلِيّك ويّستكهى لهيهكتر جياواز، واته له كات و ساتى جياواز، بهلاًم تهواوكهرى يـكترى كردهكه، بهكوّمهلّيّك داتاو بهلّكَهنامهىى سهلميّنراو، بخهينه روو. يِّيشمان وايه بهلايهنى كهم ئهمهى ئهم بهشهى كوردستان، دهبنه سهرهتايهك بوّ

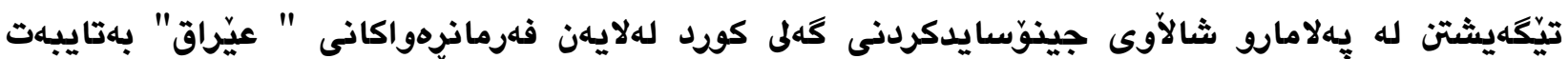
بهعسى لهكوّرنراو، هلهروهك زانيارييهكى ورديشه بوّ ناسينهوهى تاوانهكانى بهعس.

ناوهروّكى باسهكهمان لهم ناونيشان و بهشانهى خوارهوه يِّيكديّت (بهرجياو رِوونى، بهرخورديّك بوّ

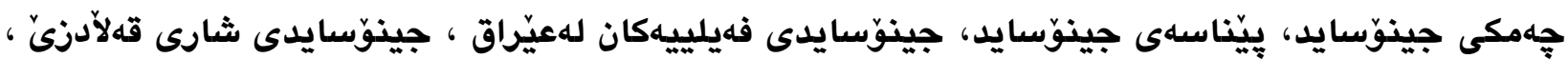

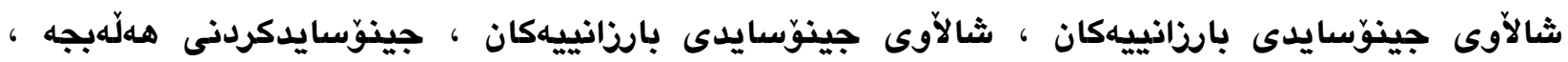
جينوّسايدى ئهنفال ، هيّرشه كيمياوييـكان له كوردستان ، ينوّسايدى "باليسان"، جينوّسايدو

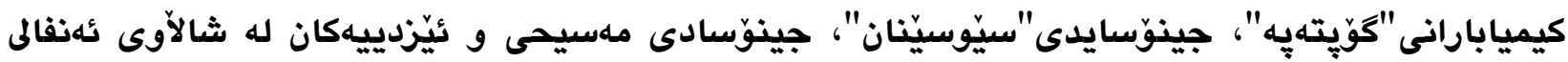

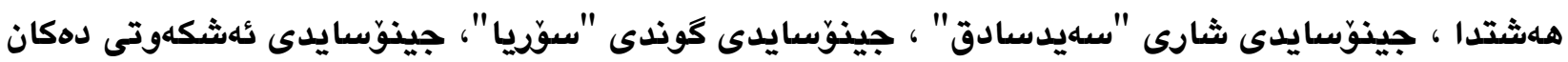

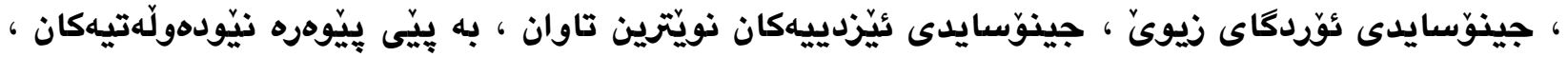
دوّسييهى تاوانهكان له دادگًا ، ثٔهركى ئيستاو ئايندهان؟، لهسهرئاستى عيّراق، لهسهرئاستى يهرلهمانى كوردستان ، لهسهرئاستى سهروّايهتى هـريّم و حكومهتى هلريّمى كوردستان ، لهسهرئاستى ريّكخراوهكان ،

$$
\text { لهسهرئاستى نيّودهولِهتى و هـريّما يهتى). }
$$

بيّكومان قسهو بوّجيون و ليّكدانهوهو خويّندنهوهى تر زوّرن، رهنكه كرنكترين خالّى هاويهشى ئهمهى

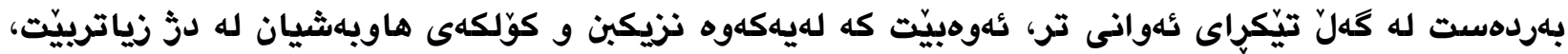

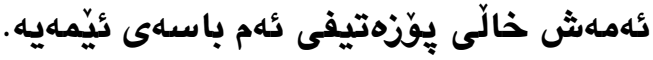




\section{بلهرخورديّاك بوْ جهمكى جينوّنسايل}

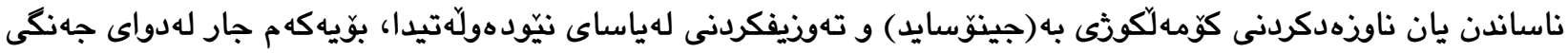
دووهمى جيهانى هاتهكايهوه، كه تيّيدا كرنكترين ماف كهمافى بوون و ريانه، له بهندى سيّيهم له جارينامهى جيهانى

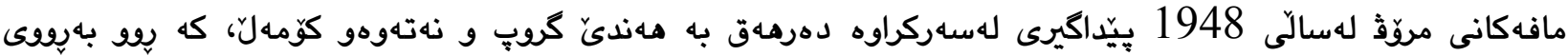
جينّوسايد كراونهتهوه.

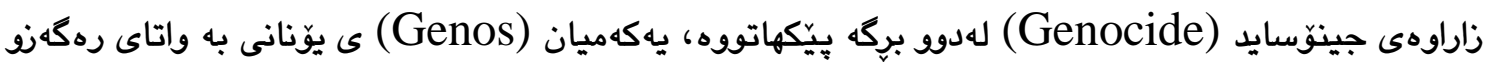

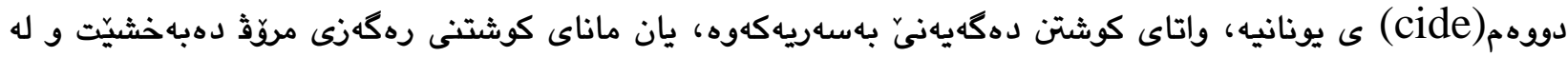

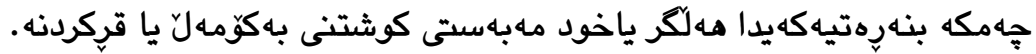

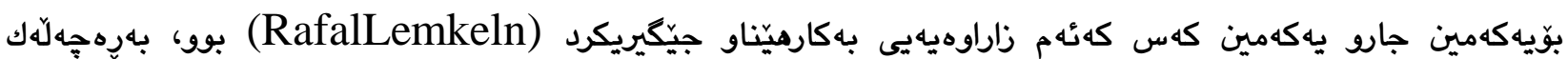

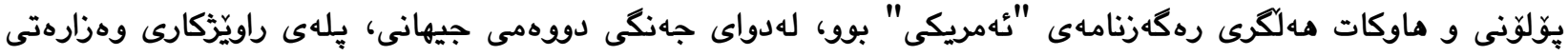

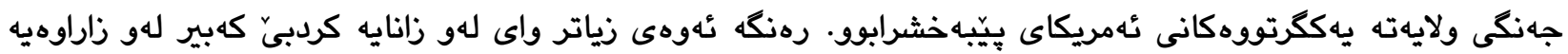
بكاتهوهو به ديارترين تاوان يان تاوانى تاوانهكان يِيناسهى بكات و بيناسيّنيت، بهدهرلهوهى كهخوى شارهزاى ئهو بواره بوه، ئهوهبويّيت كه خانهوادهكهى دواى ئهوهى كهوتنه دهستى "نازييهكان" كوّمهلككوزكران، وهك سهدان مهزار جولهكه كه جينوسايدكران.

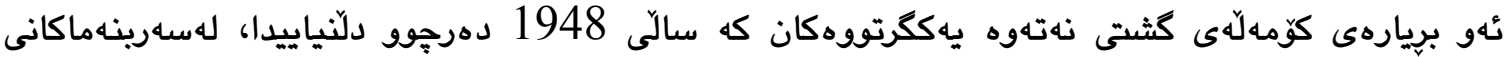

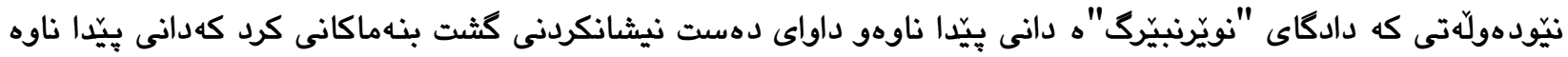

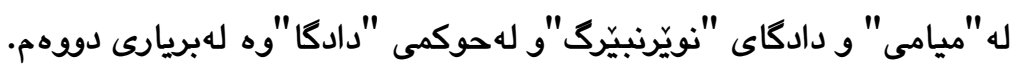

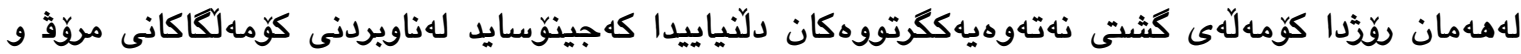
لهناويردنى مافى زيانى تاكهكانه لهههموو توخم و رهكهزهانى مروّايهتى و لهم بارهشهوه ريّكهوتننامهيهك دهربارهى

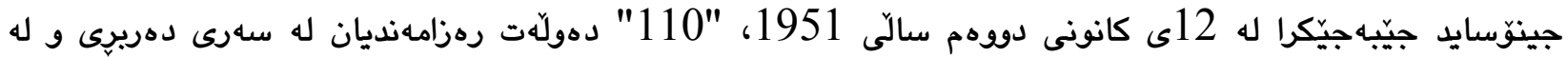

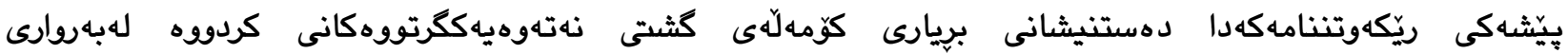

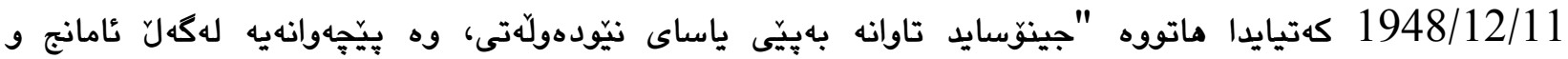

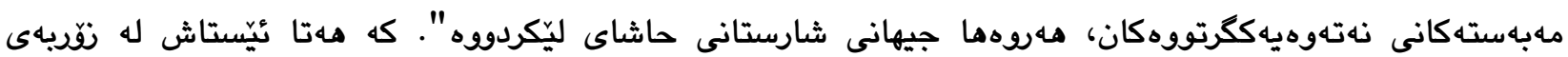
حالَهته كاندا، وهك مهرجيّكى سهرهكى و نئيلتزام لهسهرشانى دهولّهتهكان دادهنريّت.

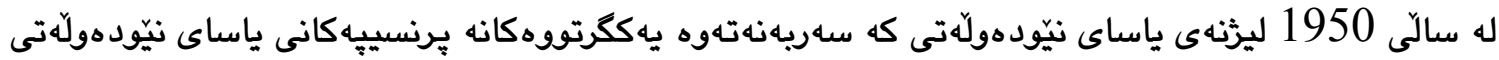

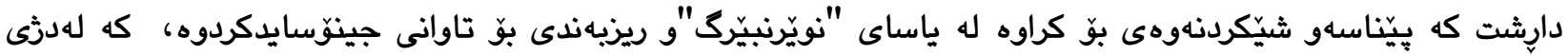

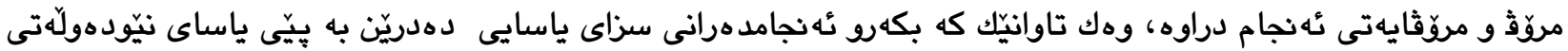

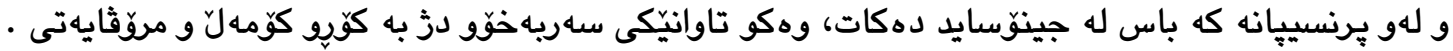

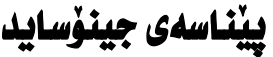

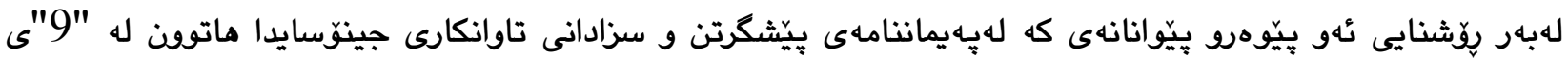
ديسمبهرى سالّى 1948 لهلايهن كوّملّهى كشتى نهتهوه يهكگرتووهانهوه ماتووه، وهكو برِياريّكى تايبهت بهزماره 
(260) بلّاوكراوهتهوه، دهتوانين كوّى تاوانهكانى دز به كَلى كورد وهك "ئهنفال، جينوّسايدى بهرزانيهكان، كيميابارانى

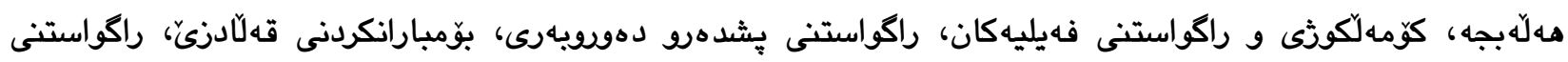

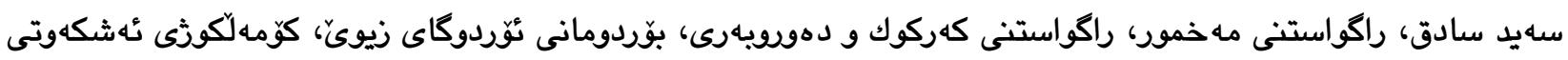

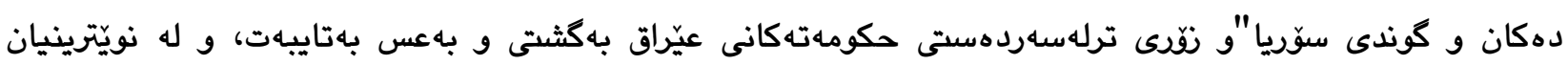

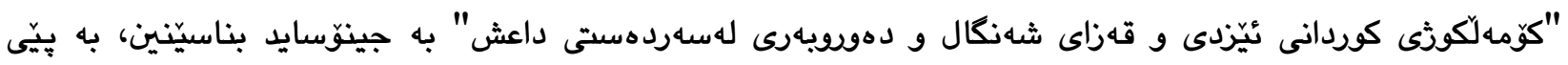

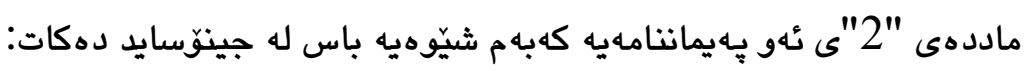
ا-جينوّسايد مهموو ئهو كردهوانهى خوارهوه دهگريتهوه كه مهبهستى لهناويردنى تهواو يان بهشيّك له كرويِيّى نهاتهوهيى، ئهتنيكى، رهذكهى و ئاينى نئه نجام دهدريّت، بوّنموونه: 1 -كوشتنى ئهندامانى كرويـكه.

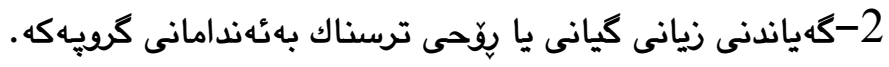

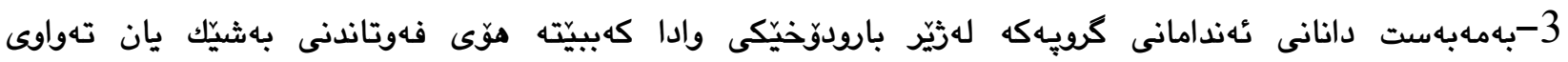
• ئه ندامه كانى

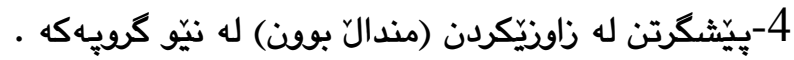

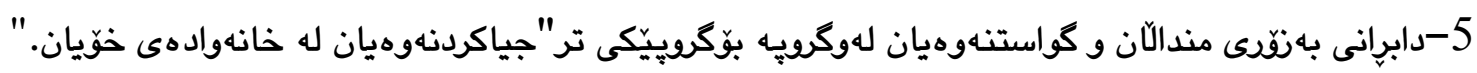

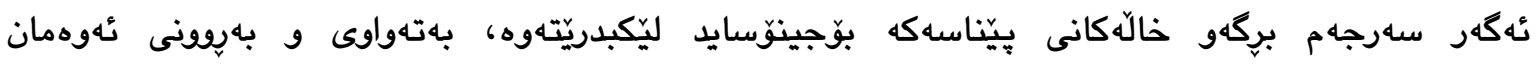

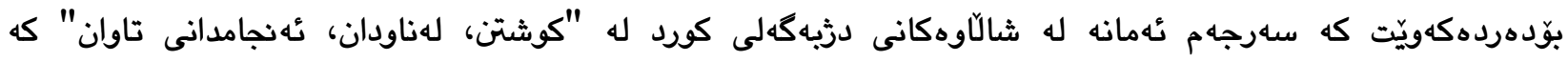

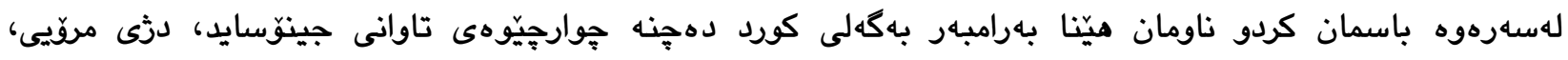

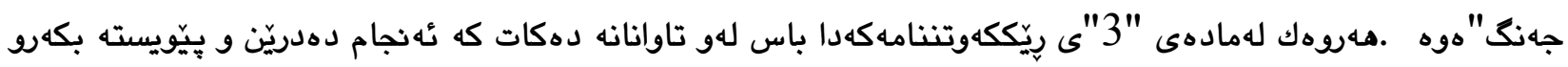
ئهنجامدهرانى سزاى ياسايى بدريّن و وهربكرن، ئهوانهش ئه م كاراكتهرانهن:

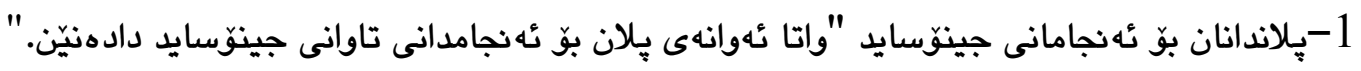

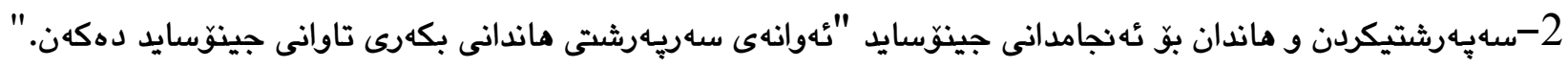

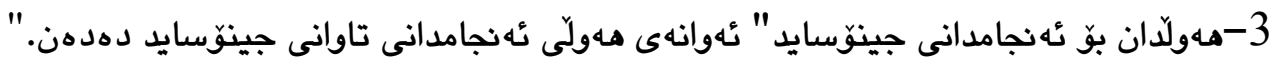

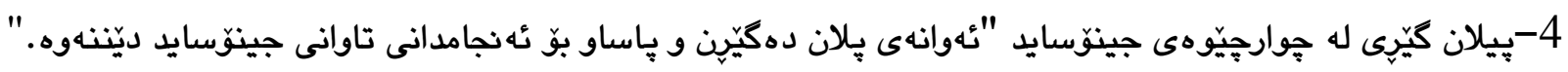
بهيوختى، يِيّناسهى جينوسايد بهيِيَى برِيارى رِيّكخراوى نهتهوه يهكگرتووهان كه بريارى زماره (96) بوو له

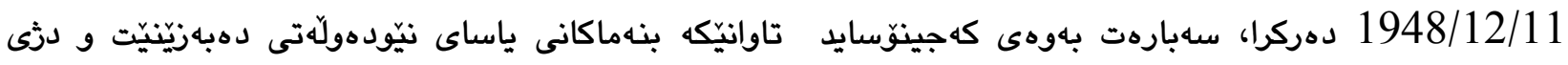

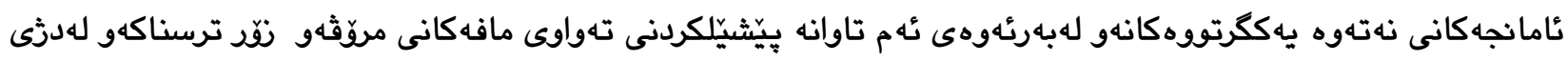
مافى زيانهو تيّكدهرى نَاشتى و ئاسايشى نيّونهتهوهييه، بوّيه برِيارى ئهوهى لهسهردراوه كه تاوانيّكى دريندانهيه لهدثى

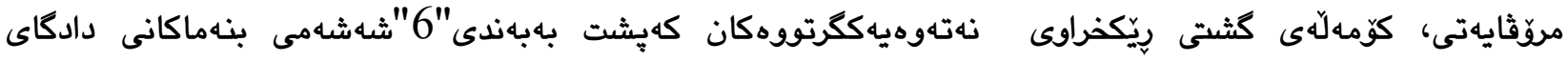

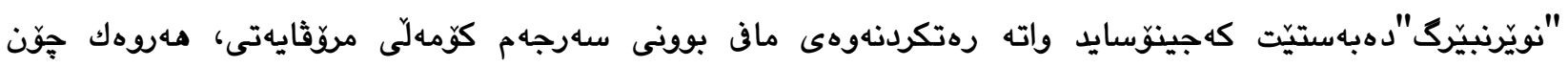


نيشانهى رهتكردنهوهى ماثى بونى زيانه، ئهويش رهدكردنهوى دانيّيّانانه بهمافى بوون و سوكايهتيكردنه بهسهرجهم

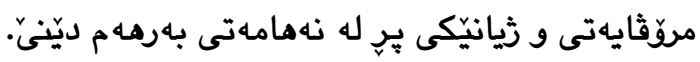

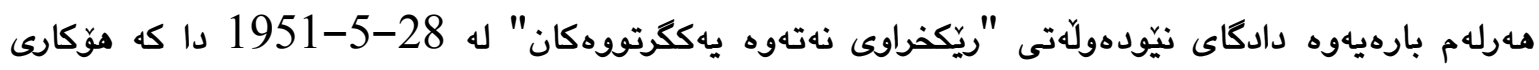
دانانى ئهو پِهيمانتامهيه نٔامانجى ريّكخراوى نهتهوهيهكگرتووهكانه كه جينوّسايد مهحكوم بكات و سزاي بخاتهسهر، وهك

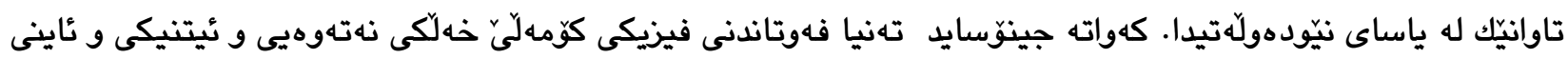

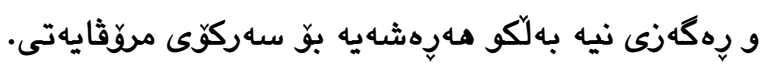

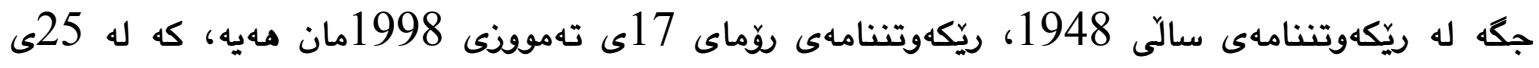

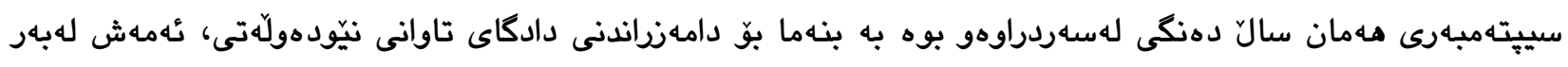

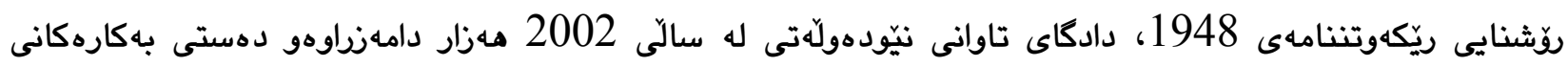

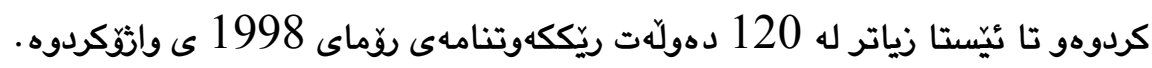

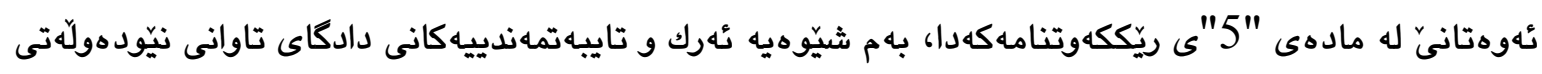

$$
\begin{aligned}
& \text { קردهدكاتهوهو دهست نيشانى دهكات: }
\end{aligned}
$$

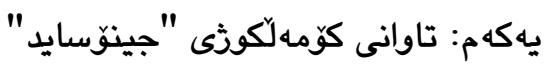

$$
\begin{aligned}
& \text { دووهم: تاوانى دزَى مروّايهتى } \\
& \text { سيّيه م: تاوانى جهنگ } \\
& \text { جوارهم: تاوانى دووثمنكارانه. }
\end{aligned}
$$

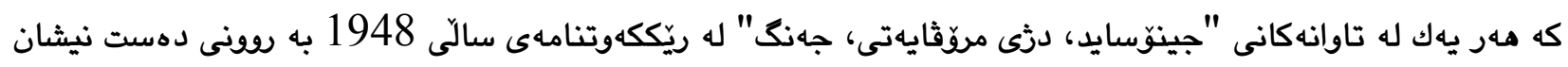

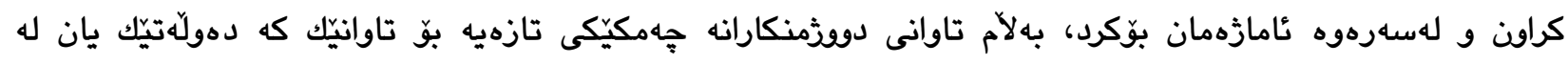

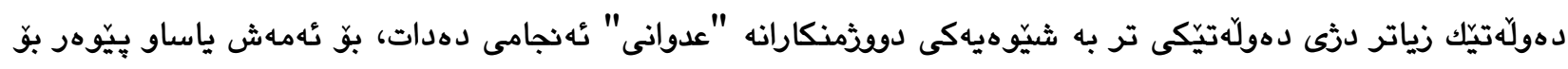
ناسينهوهى تاوانهكهو سزادانى بكهرهكهى دانراوه.

با ليّرهوه بهكورتى باسى تاوانهكانى جينوّسايد دثى كوردو كوردستان له "باشور" بكهين و دواتر مهموومان

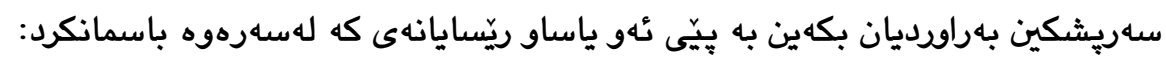

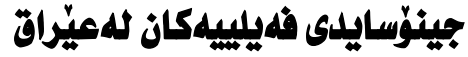

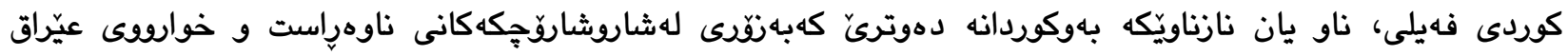

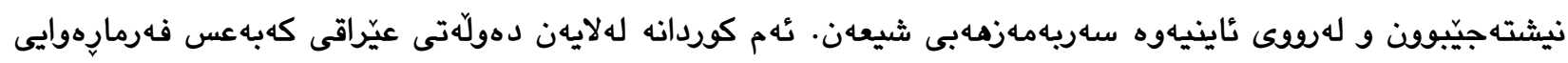

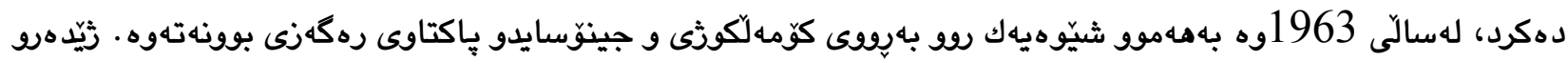

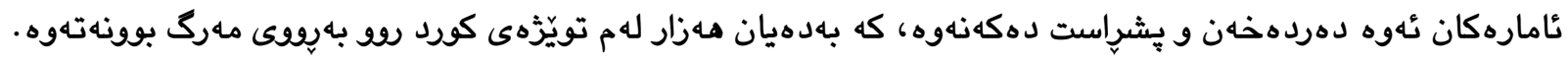

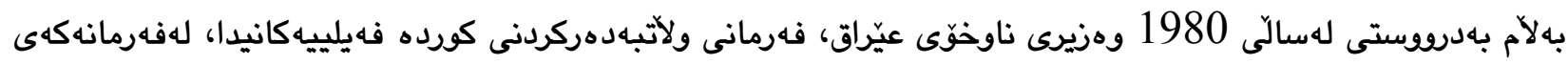

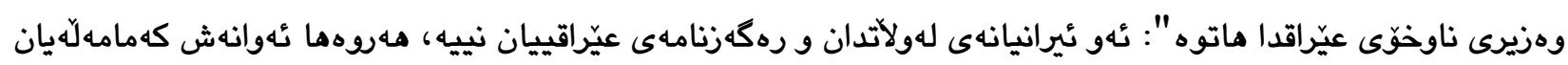

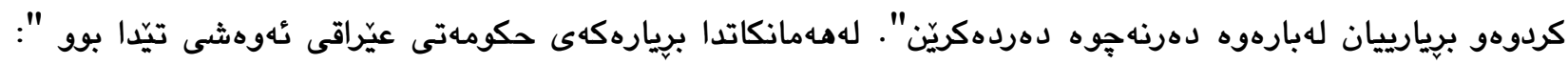


كهلاوانى كوردى فهيلى لهتهمهنى 18 تا 28 سالّ، بكيريّن و لهبهنديخانهى پِاريّزاكاندا، تاماوهيهكى ناديار

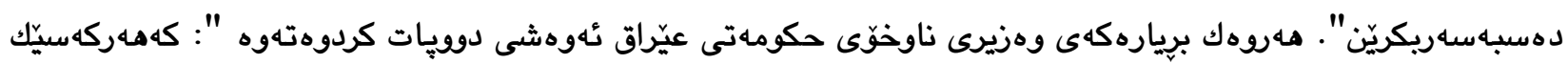

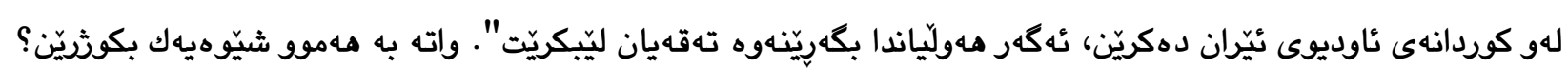

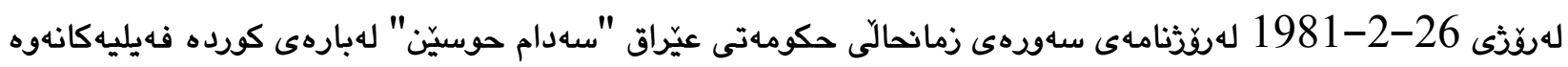

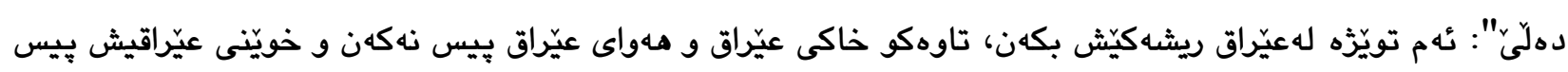

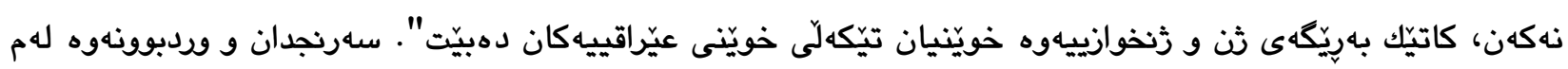

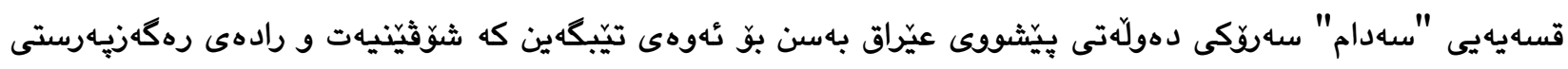
بيركرنهوهى حزبى بهعس و سهوّك و سهركردهو حكومهتهكهى لهعيّراق تاتج رادهيهك دز بهمروّ و ماوكات لهمهولّى

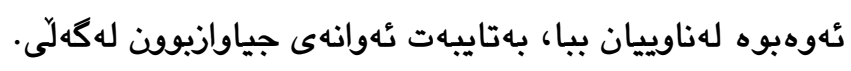

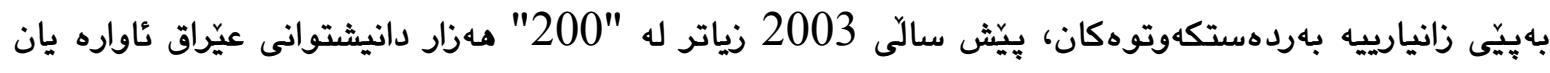

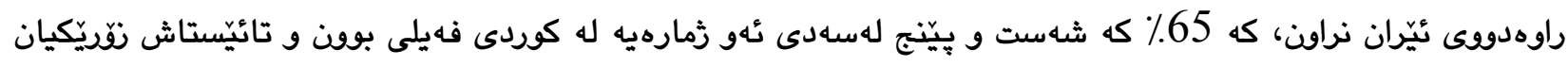
لهو ولاته ماونهتهوه. ئهمه جگهلهوهى لهماوهى دهسلاتى حزبى بهعس به مهزاران كوردى فهيلى زيندانى كراون و له لهيّداره دراون و كوّمه لكوثى كراون.

ثِيدهرو ئامارى تريش نقّن كهزمارهى وهدهرنانى كورده فهيليهكان لهعيّراق و زيندانى كردن و كوشتن و و

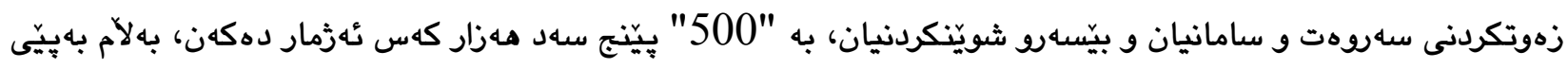

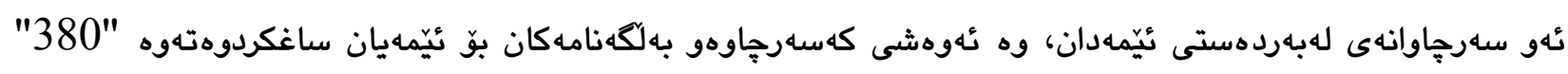
ههزار كوردى فهيلى روق به يووى قركردن و جينوّسايكردن بوونهتهوهو ئاسهوارهكانيشى تا تيّيستا ماون و بوّجههندين دهيهيى تريش مهرددمينّن.

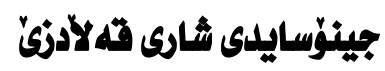

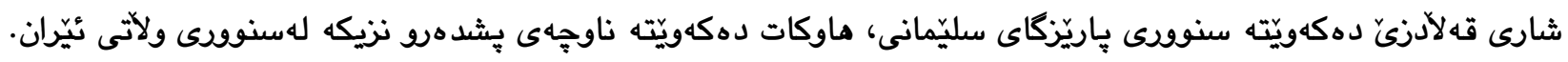

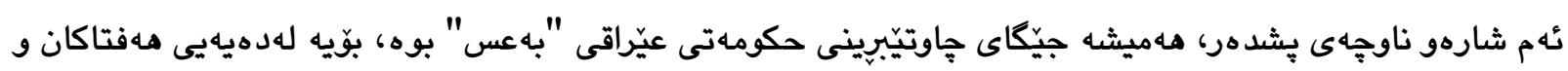

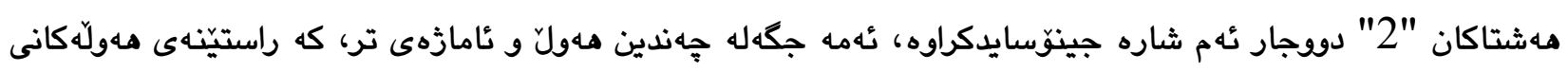

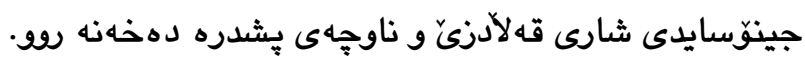

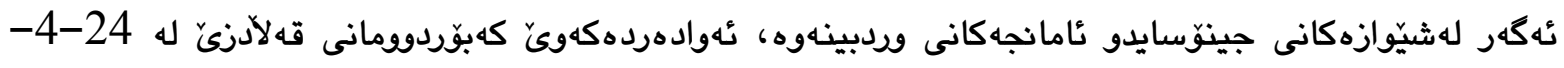

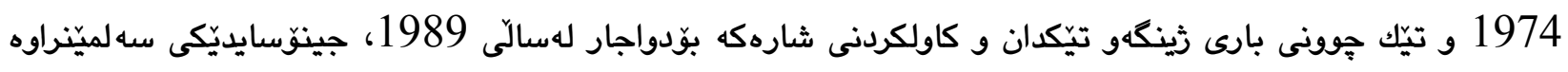

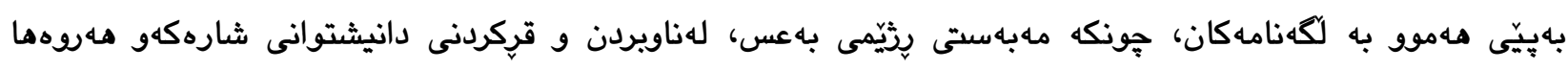

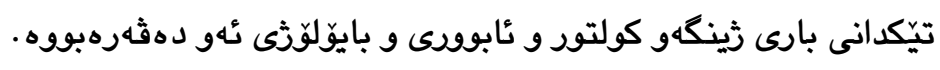

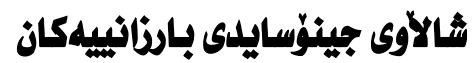

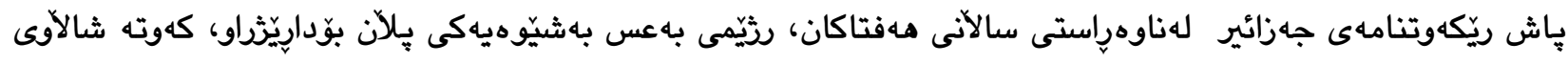

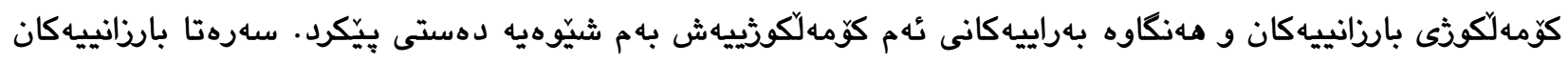




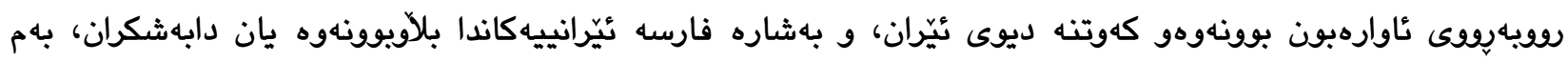

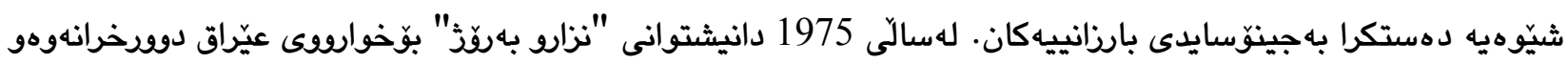

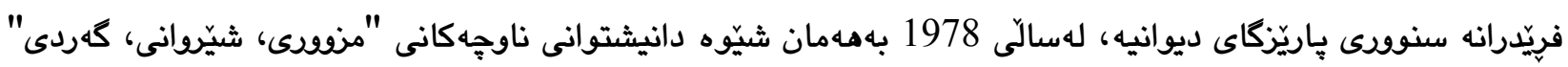

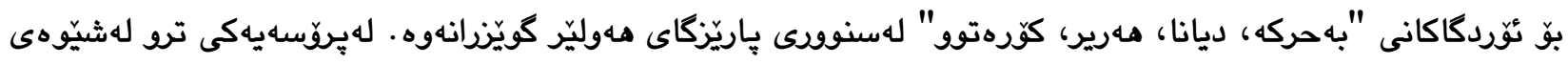

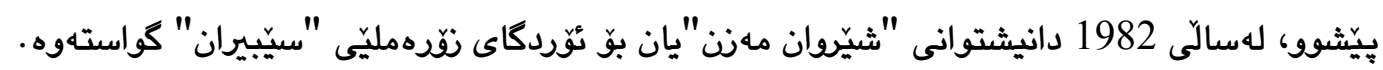
دواترو دواى ئهو مهنكاوه بهراييانه، كردهوهى كومهلكوثى بارزانييهكان بهشيّوهيهكى فراوانترو كردارى لهلايهن

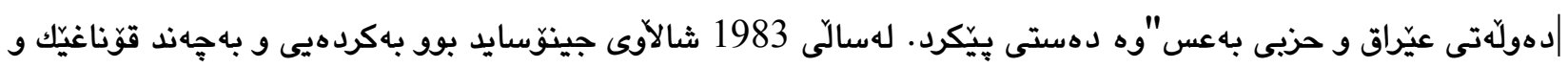

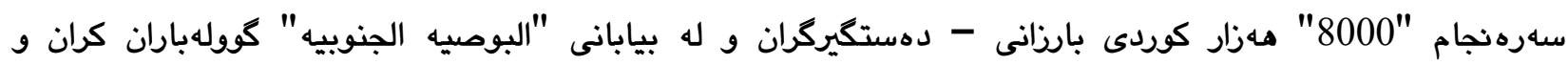
"جينوّسايد" كوّمهالكوزكران.

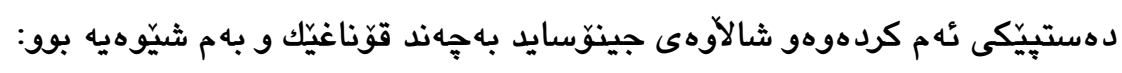

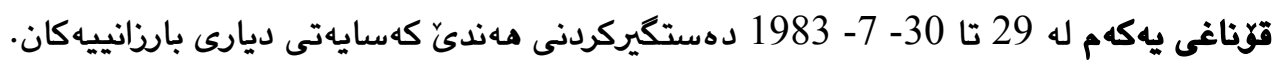

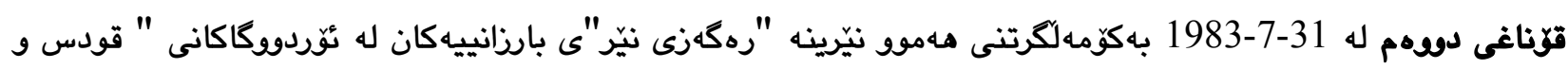
قادسيه".

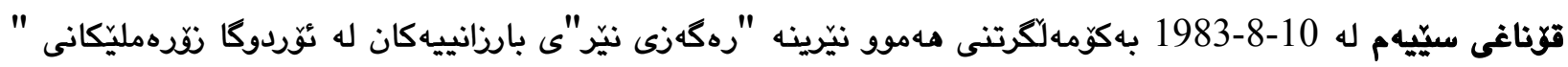
مهرير، بهحركه، ديانا". قؤناغى جوارهم راوهدوونان و بهكومهلكرتنى ئهو بارزانيانه بوو، بهههرشيّوهيهك بويّيت له شالأوهانى كرتن رزكارييان ببوو.

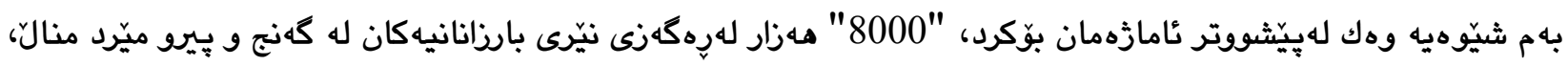

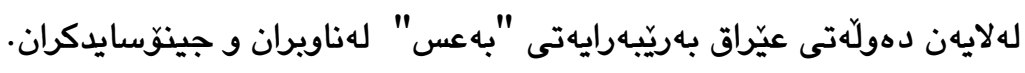

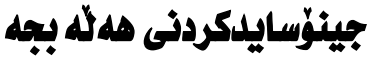

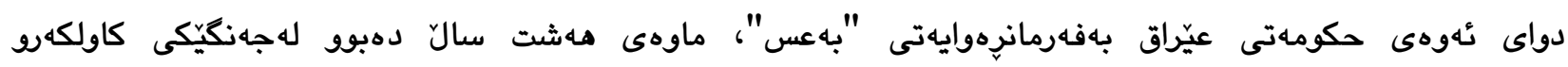

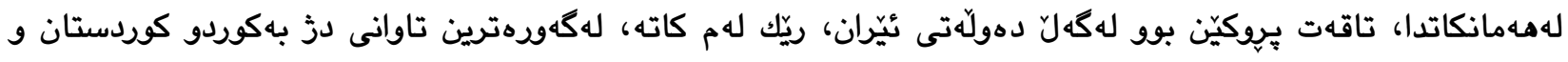

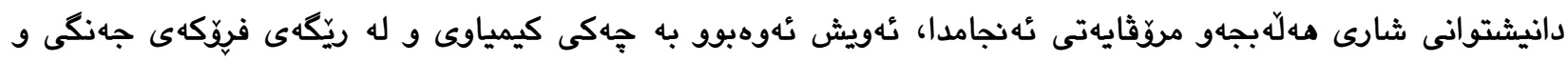

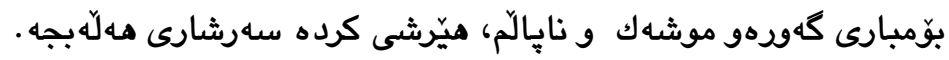

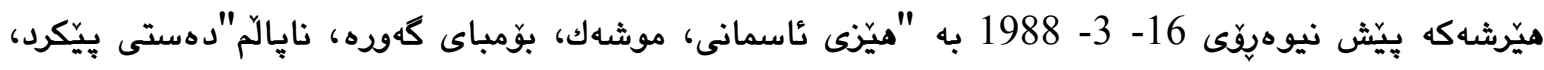

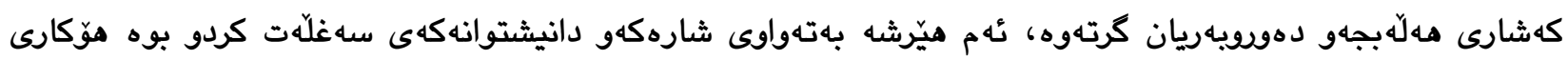

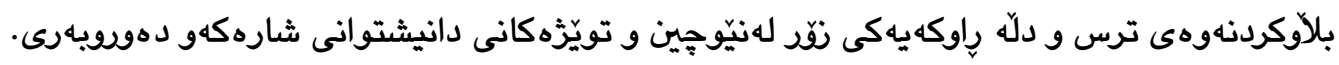

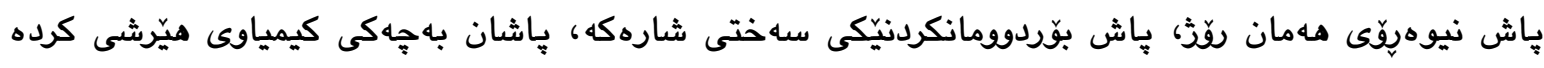

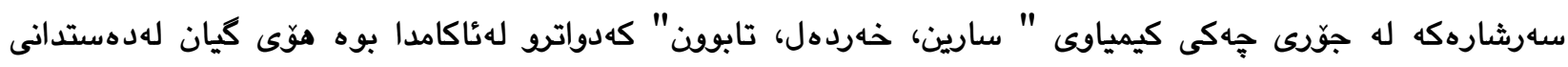


"5000" هـزار كهس لهدانيشتوانى سيثيلى شارهكهو برينداربوونى هـزارانى ترو ثاوارهبوونى ئهوانى تر كهلهِهراويّزى

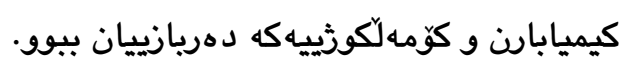

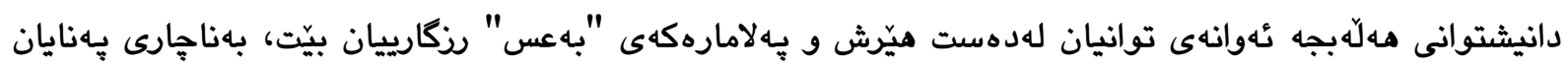

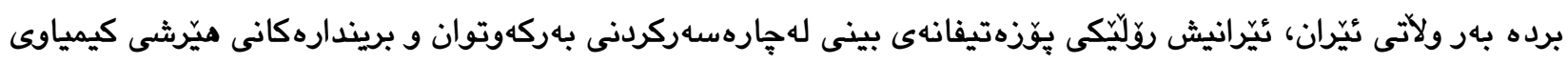
بوّسهارثشارى مه لَّبجه.

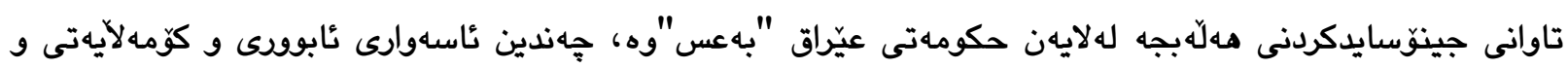
دهرونى و كلتوورى جوّراو جوّرى بهدواى خوّيدا هيّنا، كه تائيستاش بهرددوامييان مهيهو مهرجارهى بهشيّيّوهيهك دهردهكهن و روّلَى نهريّنى خوّيان داناوه.

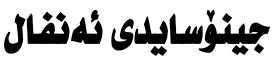

شالّاوى ئهنفال كهبههه شت قوّناغى يهك لهدواى يهك لهسالى 1988 لهلايهن رثيّمى بهعس لهعيّراق ئهنجامدرا، تيايدا

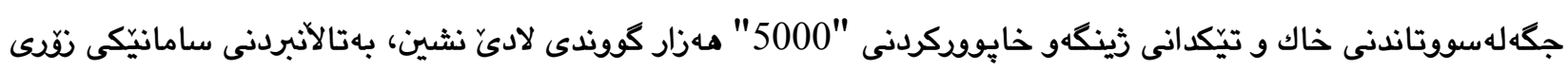

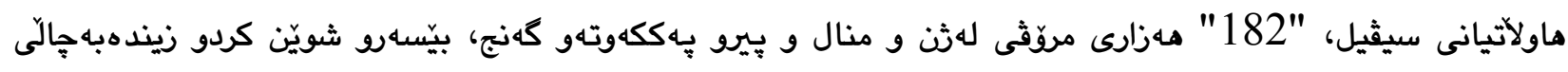
كردن.

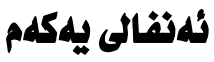
سهركهلوّو بهرگهلوّو 9 ى شويات تا 19ى مارتى 1988 (راى تريش مهيه يِيَى وايه كه 22ى شويات يان 17ى شويات

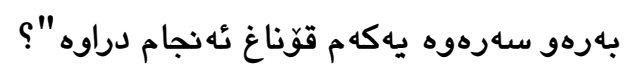

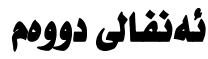
قهرهداغ 22عى مارت تا 1ى نيسانى 1988، واته له 22،ى مارت "ئازار" تا 1ى نيسان

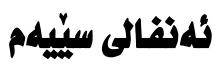
له 7 تا 20ى نيسانى 1988 دهستى بِيَكردو كوّتايى بِيّهات

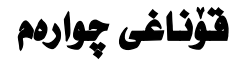

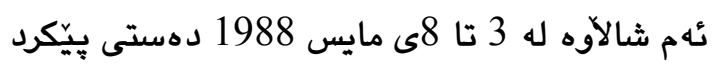

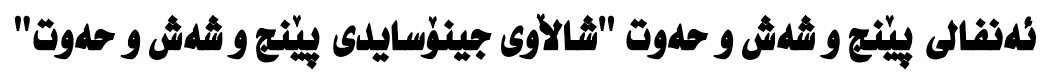

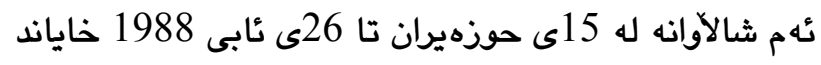

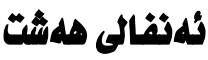

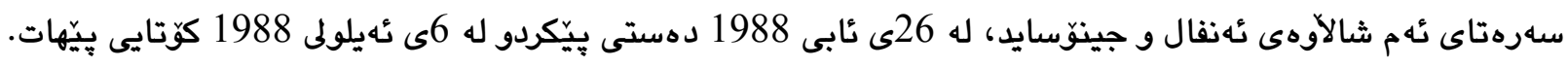

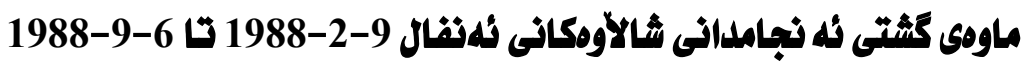
به وردبونهوه له بهلكهنامهو سهرجاوهكان، كه مهر مهشت قوناغ و شالأوهانى تاوانى ثهنفال له 9-2-1988 تا

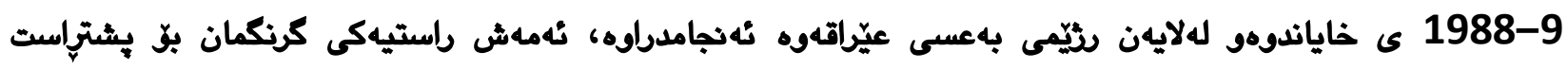




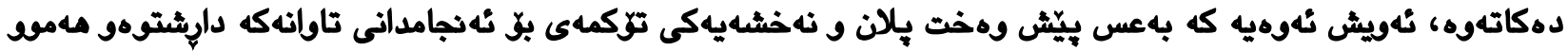
ثناماده باثشييه كيشى كردوه بوّ نُهجامدانى.

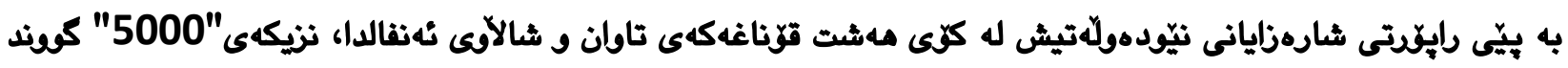

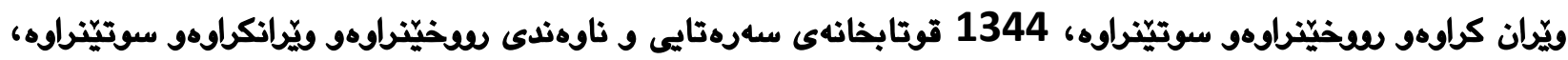

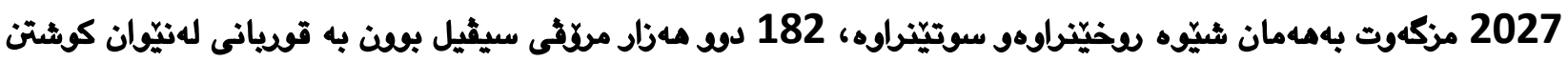

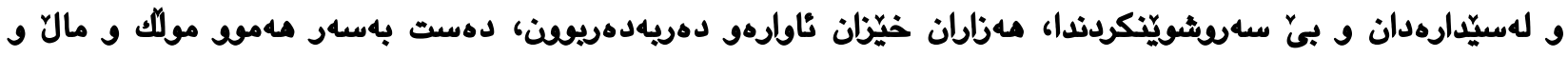

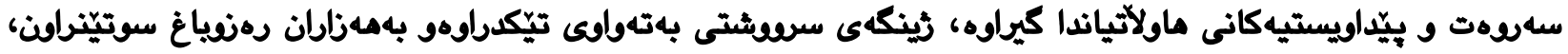

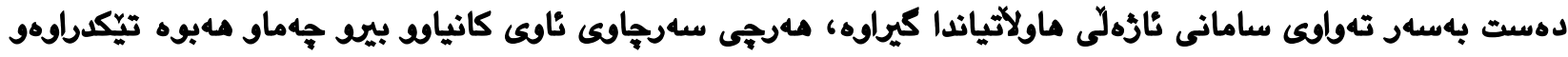

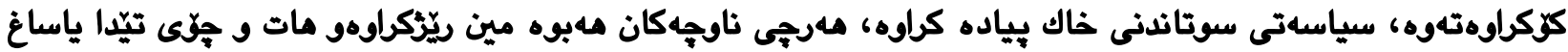

\section{هيّرثُه كيمياوييلكان له كوردستان}

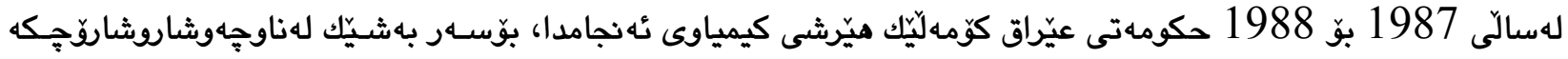

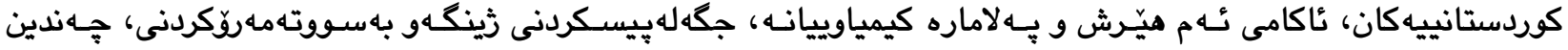

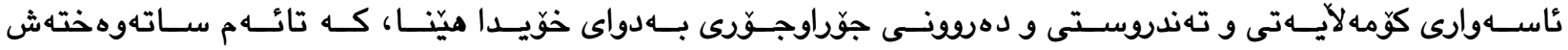
كاريكهرييهكانيان بهردهوامى ههيه. ئهمهى خوارهوه بهشيّك لهو زانياريانهيه، كه دهكرىّ بهرجاو روونييهك بدات، و كوّى

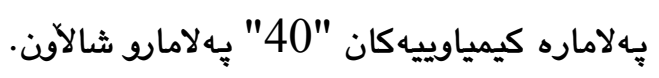

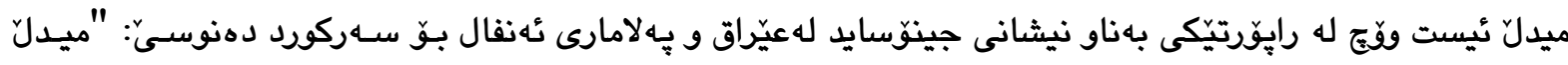

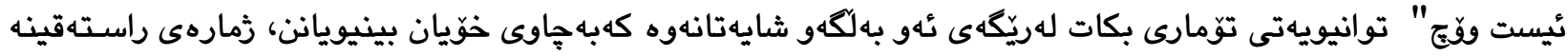

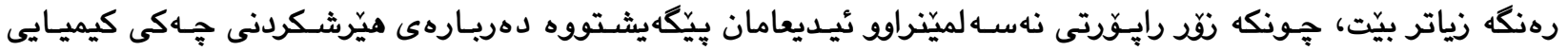

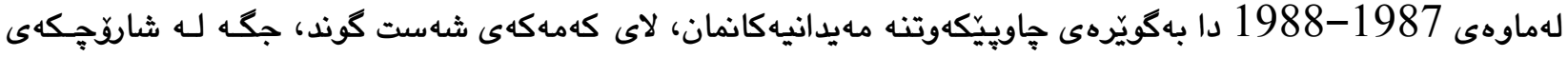

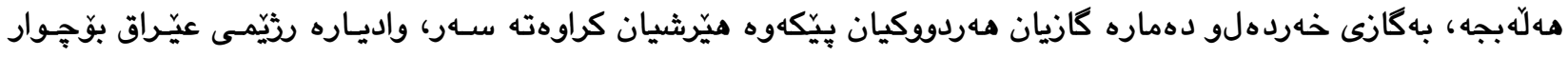

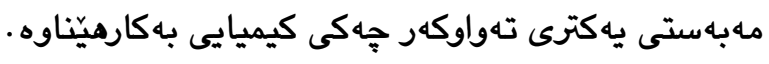

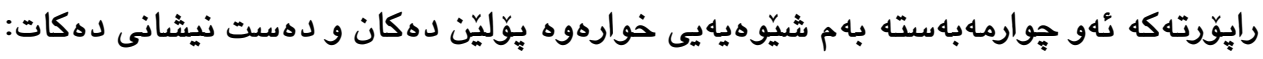

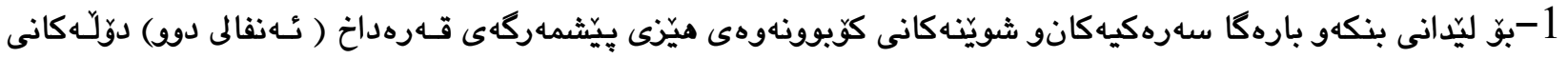

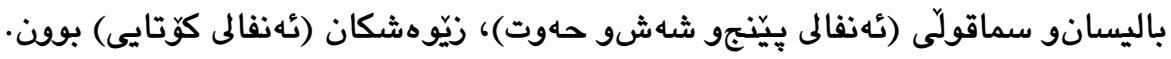

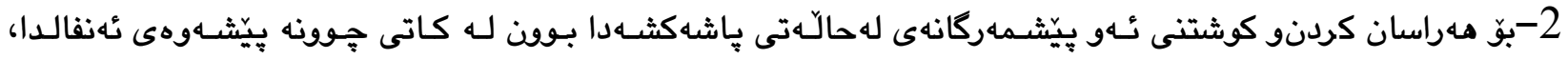

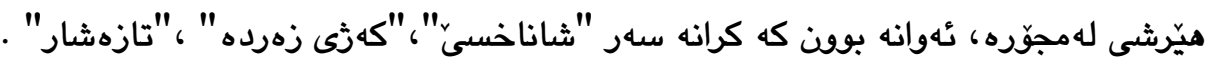

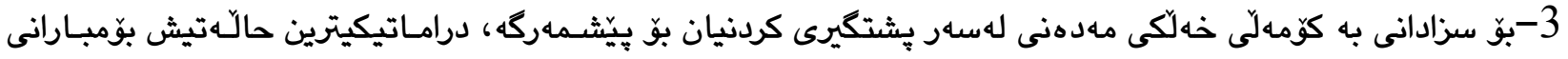

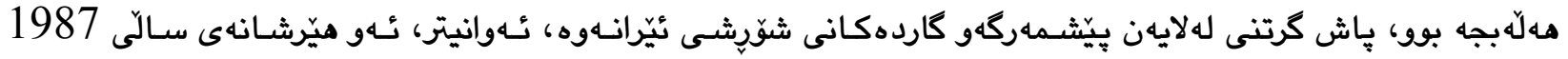

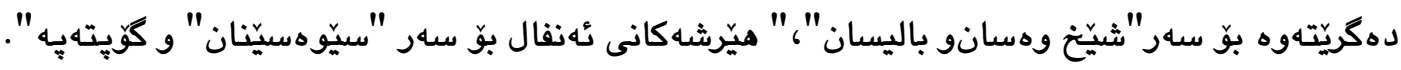

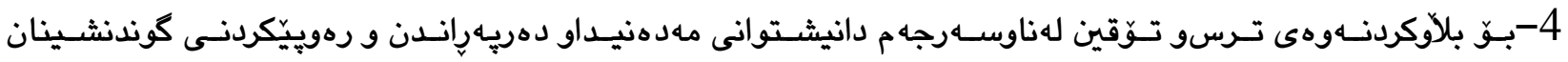

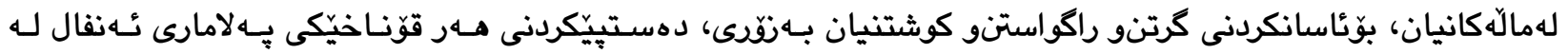




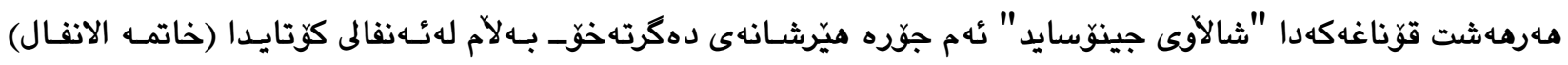

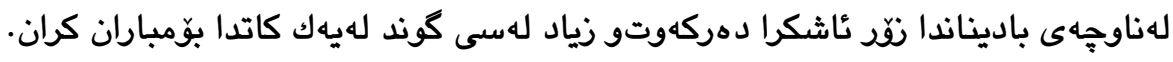

\section{جينوزسايلدى "باليسان}

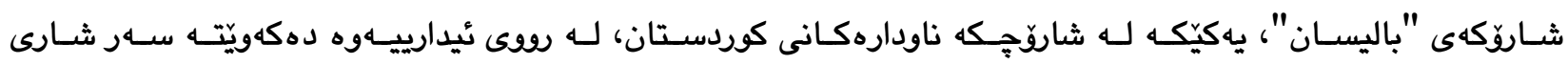

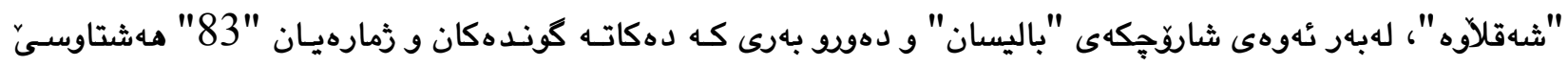

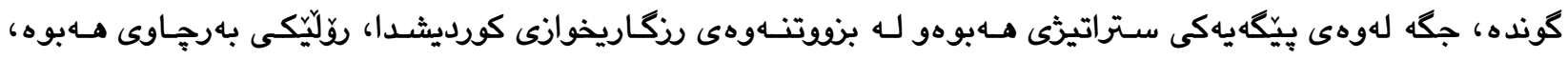

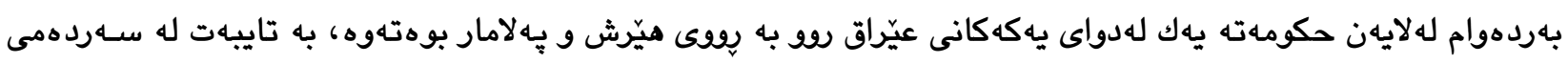

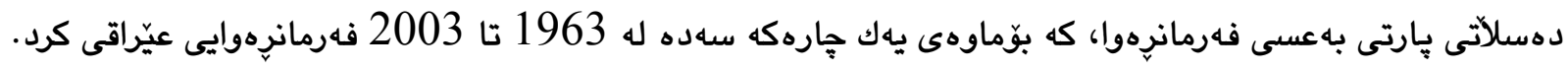

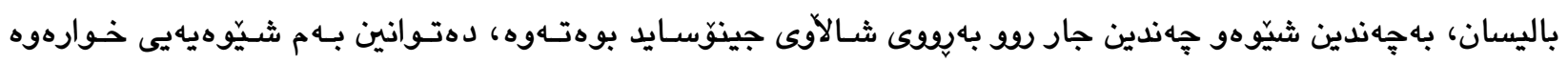

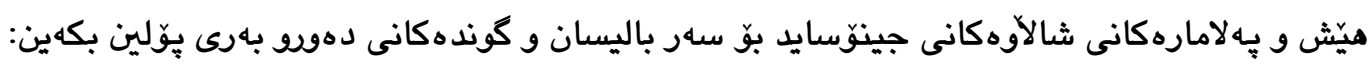

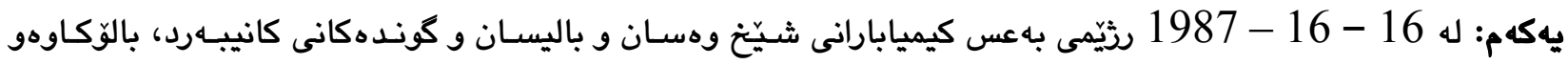

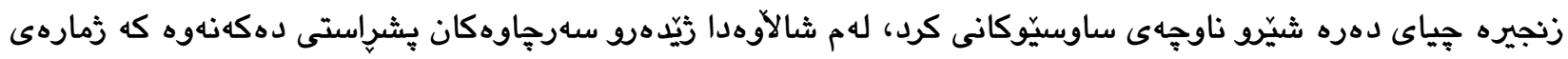

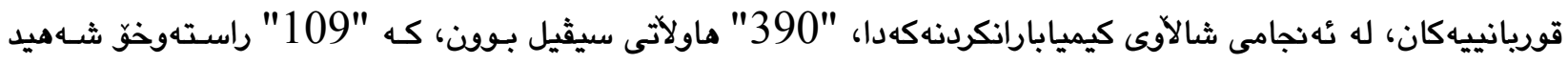
بوون و "281" كهسيشيان بريندار بوون و دواتر نقريان له ئهنجامى سهختى برينهكانيان كيانيان له دهستدا. دووهم: له 21- 4- 1987 جاريّكى تر دوّلّى باليسان دهكهونه بهر شالأوى كيميابارانكردنى فيوّكهكانى بهاعس و زهرهرو

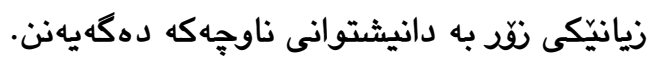

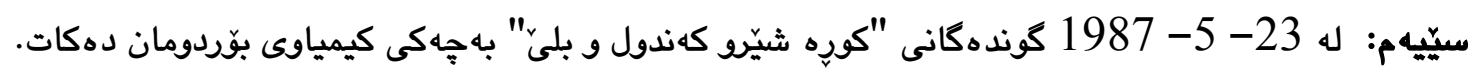

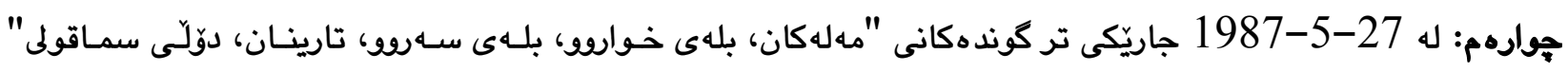

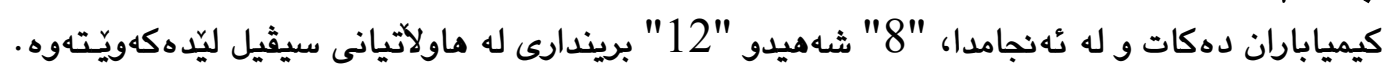

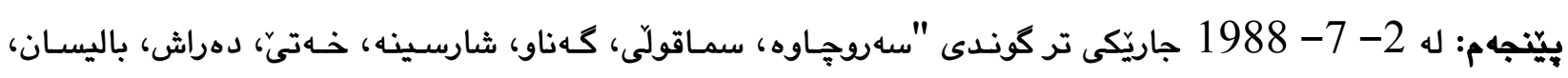

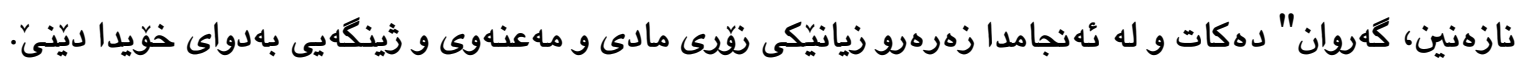

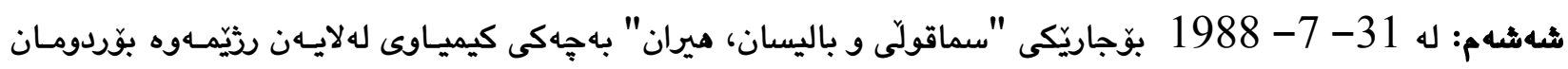

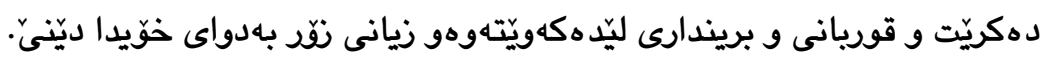

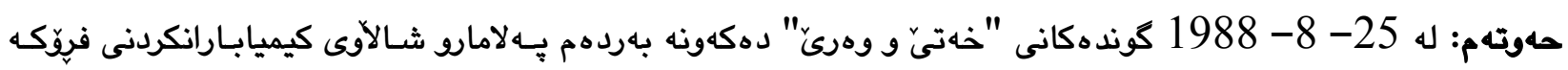

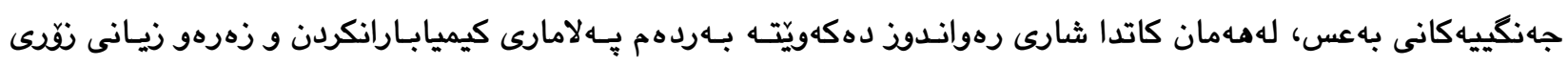

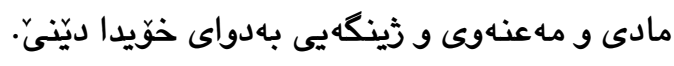

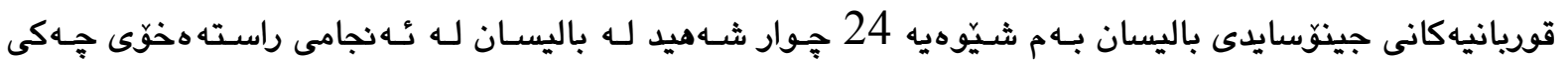

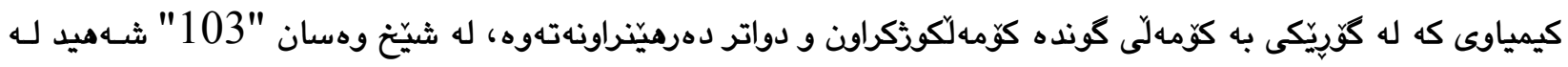

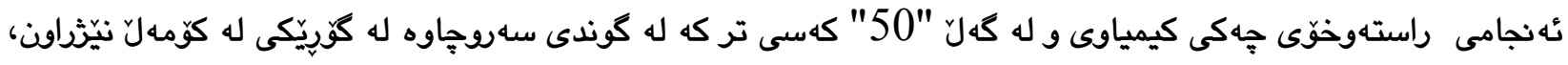

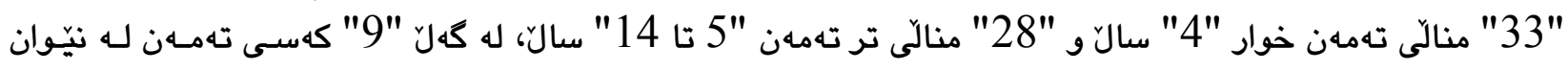

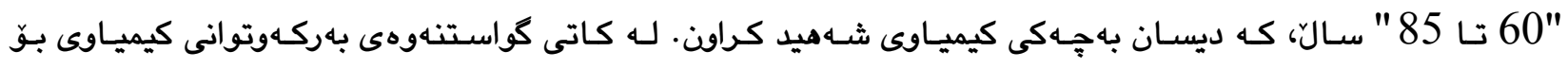




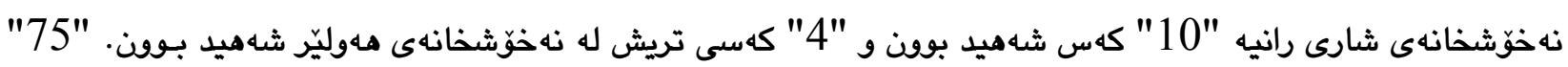

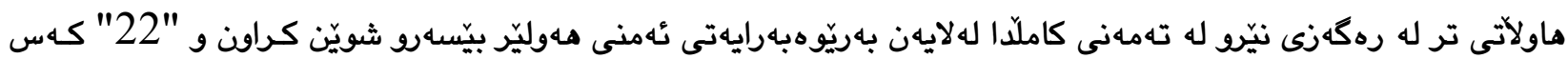

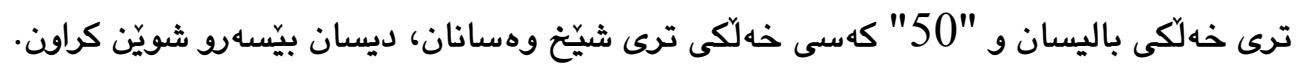

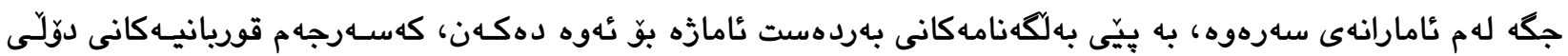

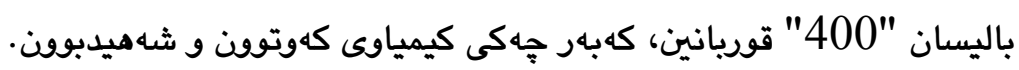

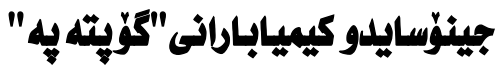

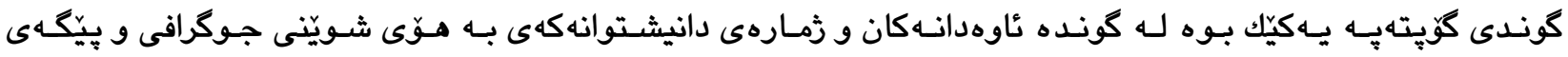

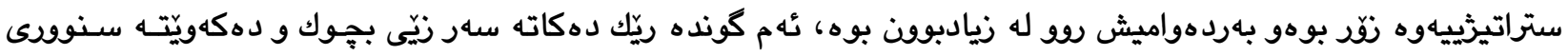

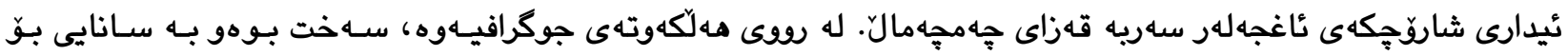

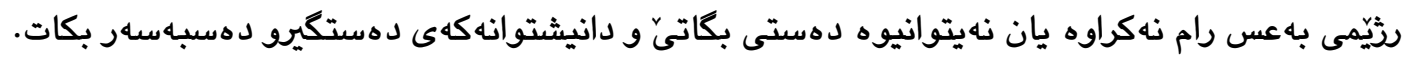

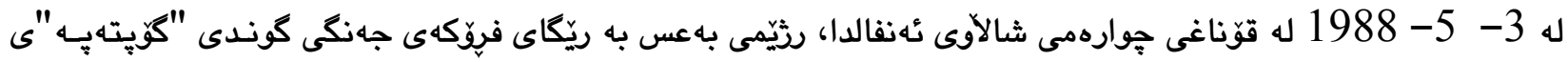

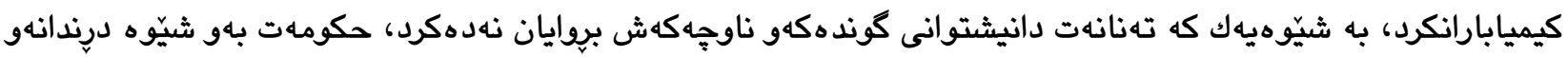

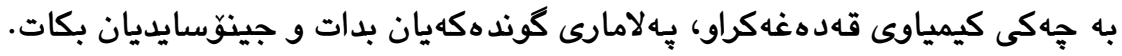

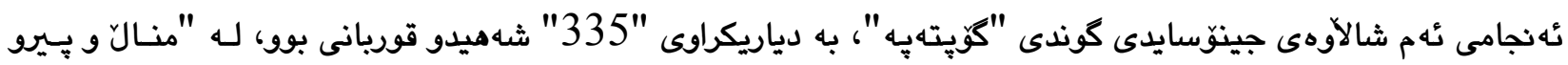

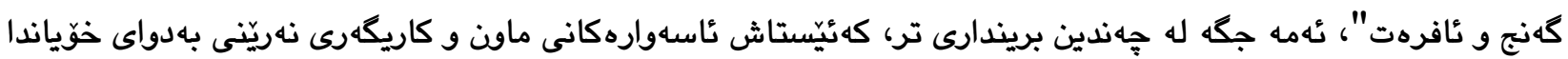

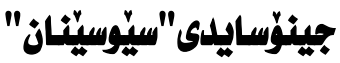

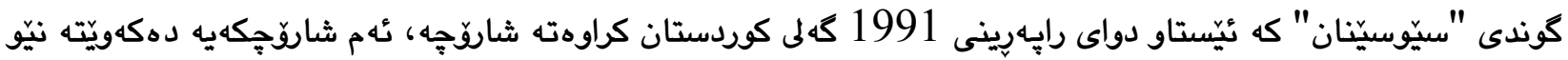

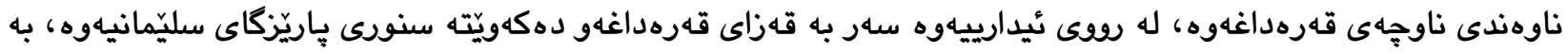

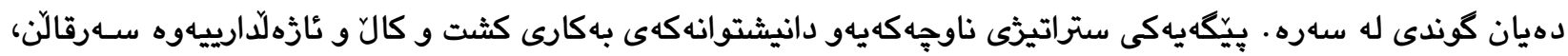

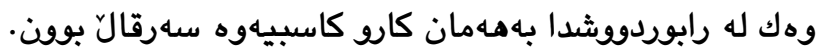

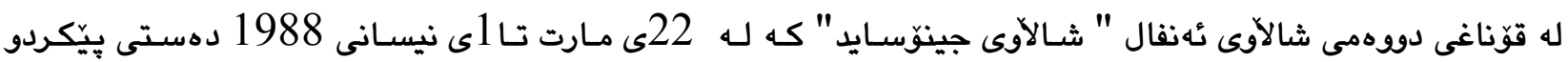

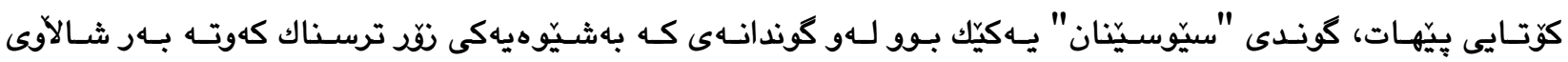

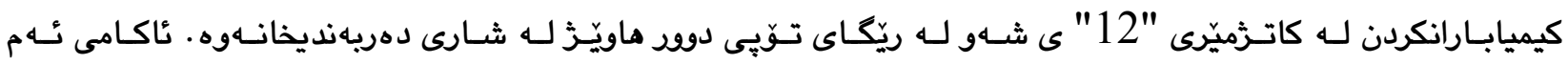

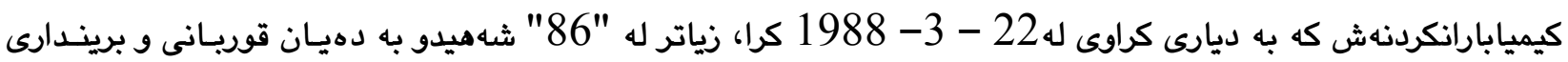

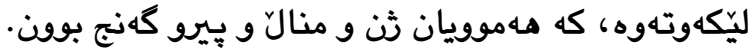

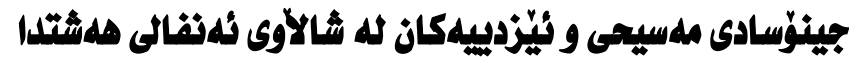

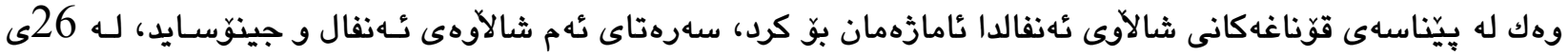

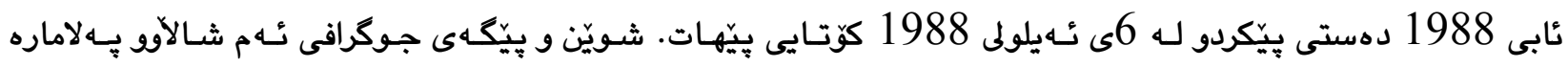

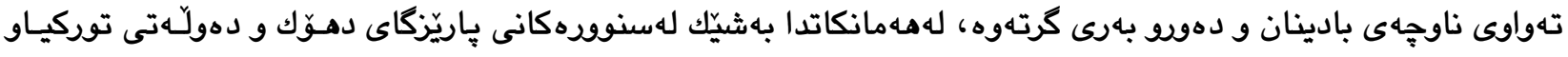

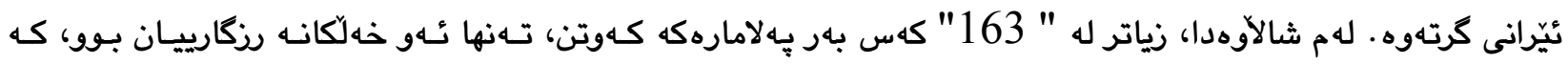




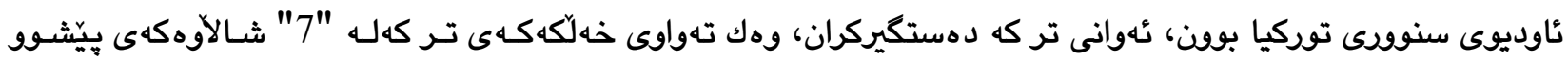

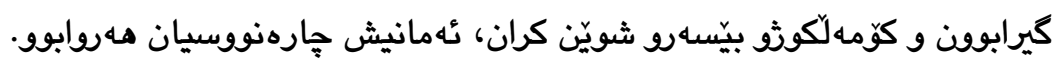

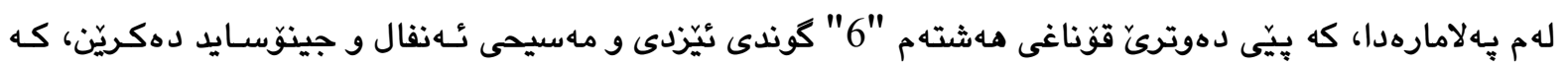

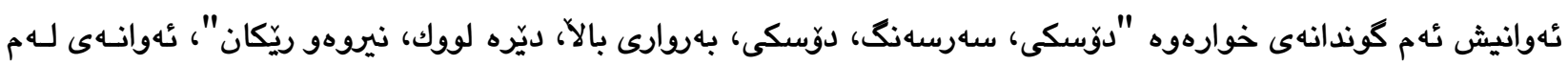

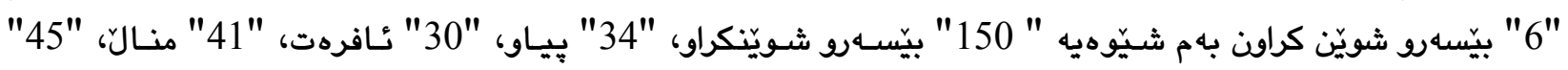

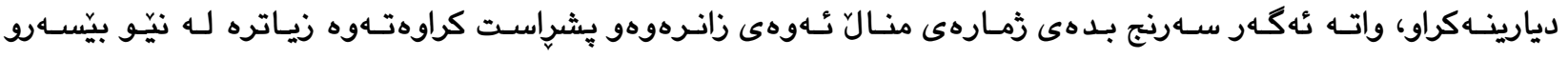

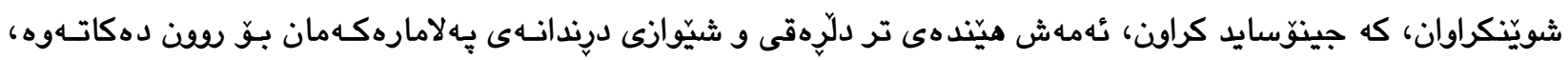

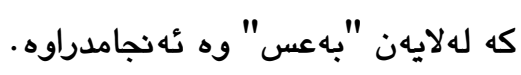

\section{جينّوسايلدى شُارى "سلهيل سادق"}

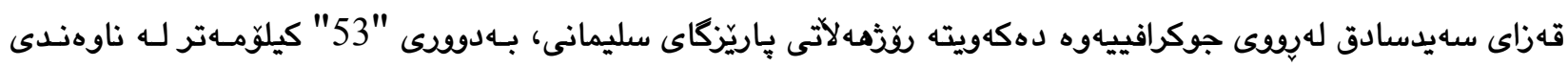

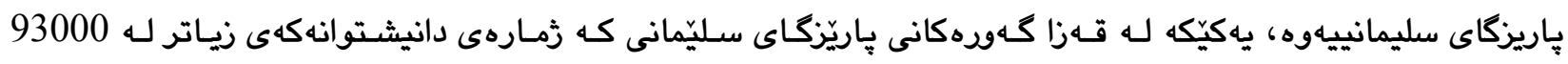

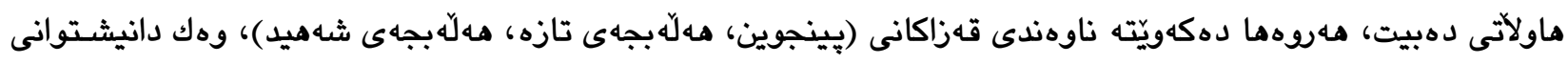

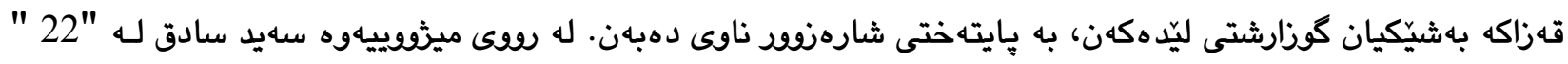

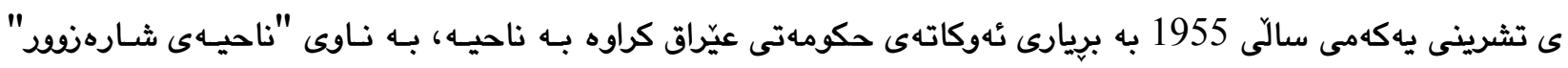

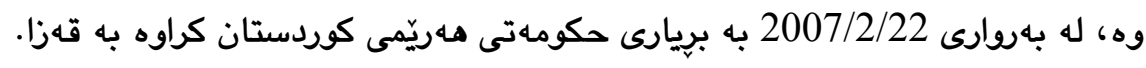

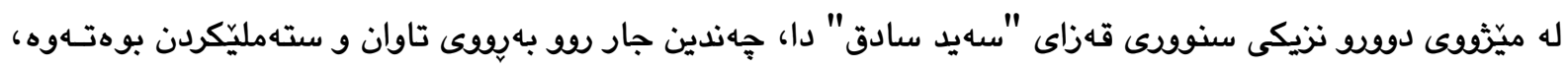

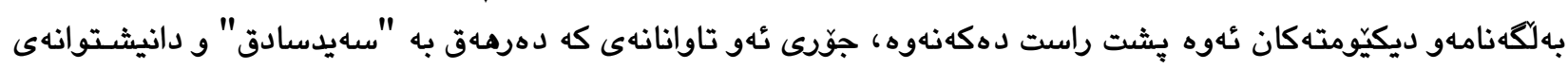

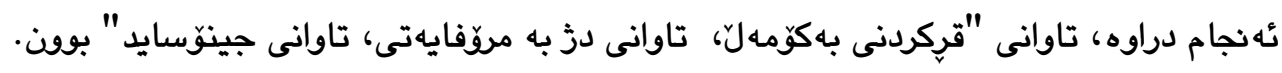

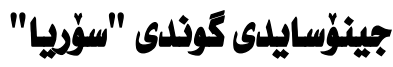

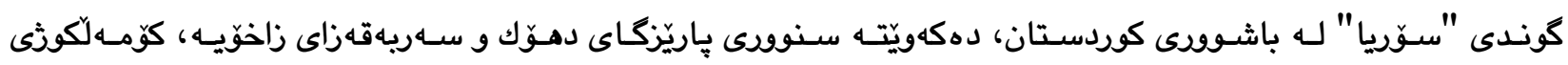

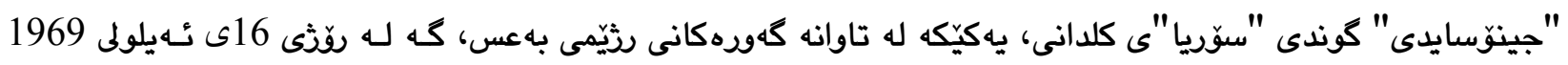

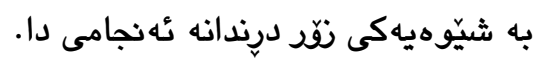

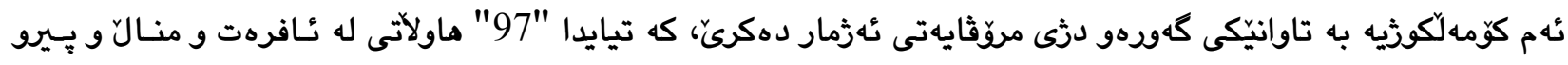

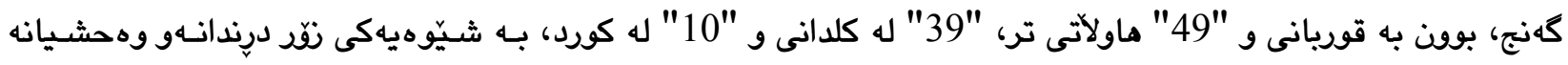
كوثران و سوتينتران.

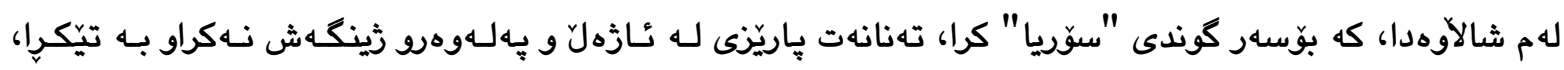

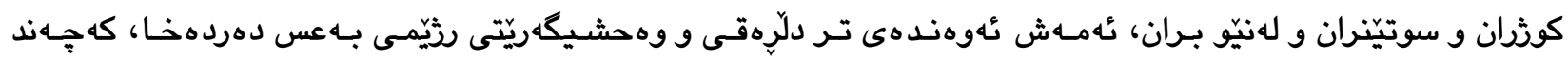

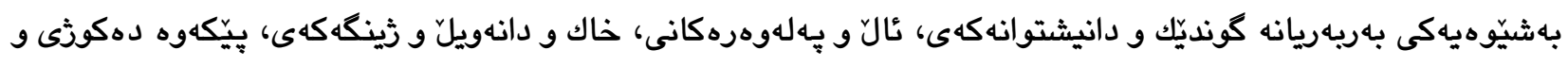

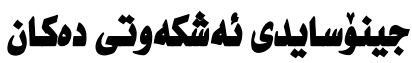

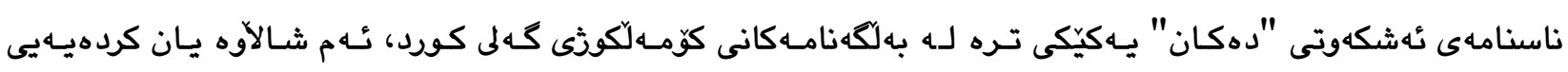

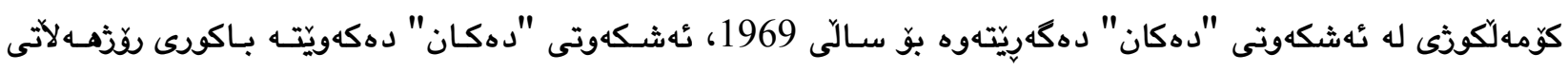




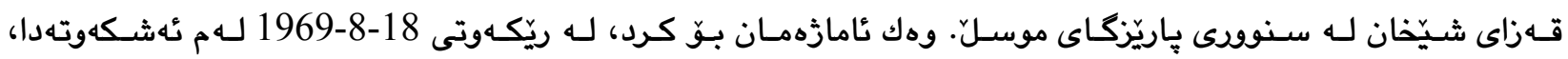

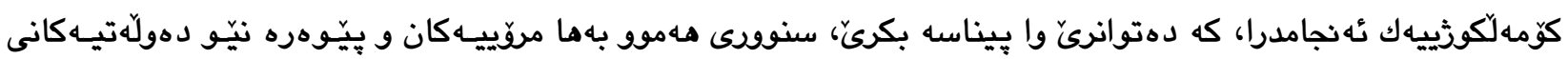

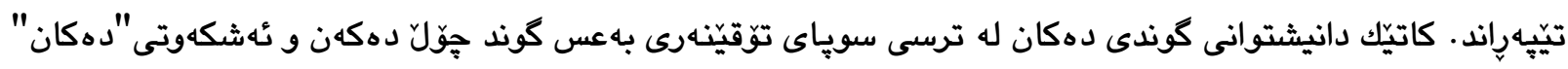

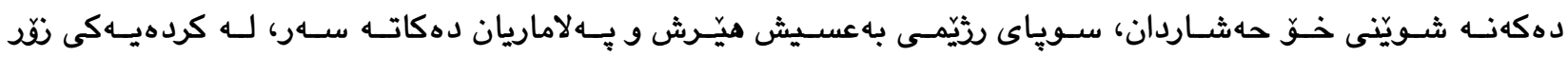

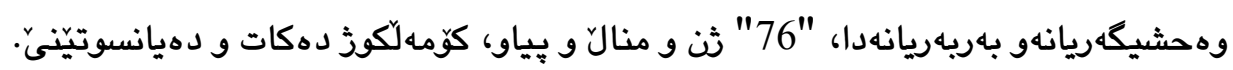

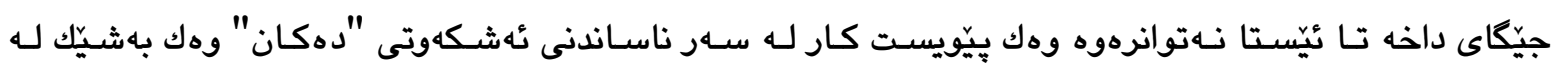

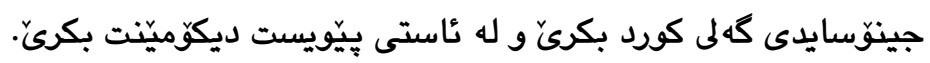

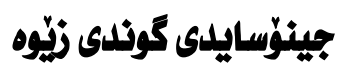

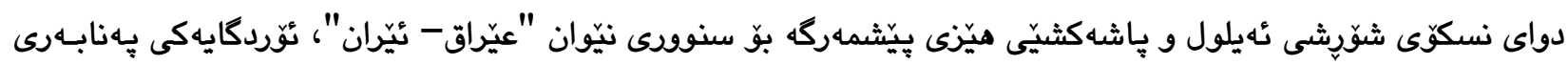

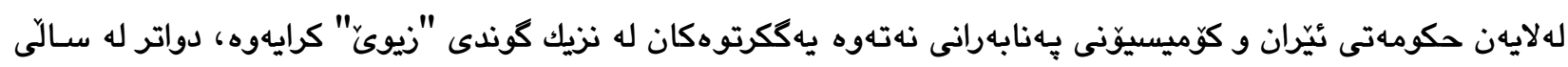

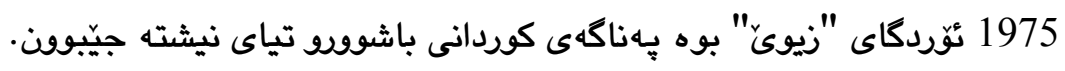

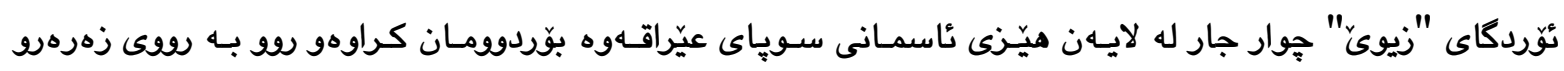

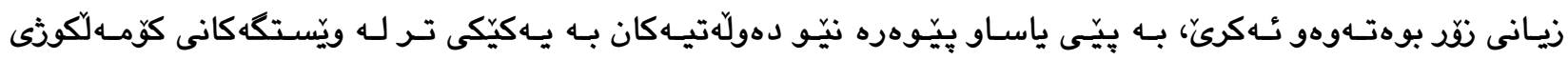

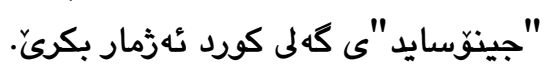

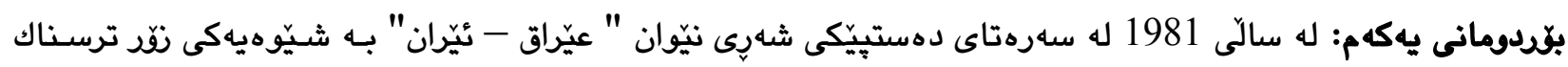

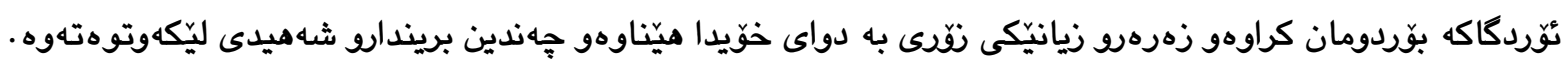

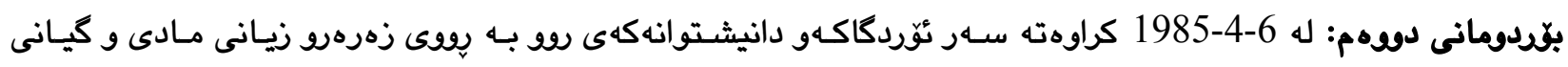
كردوهتهوه.

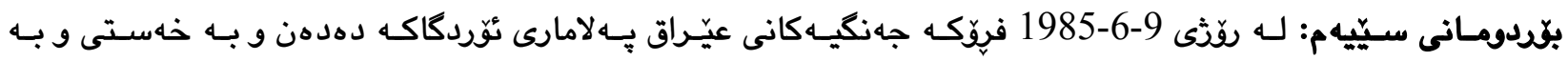

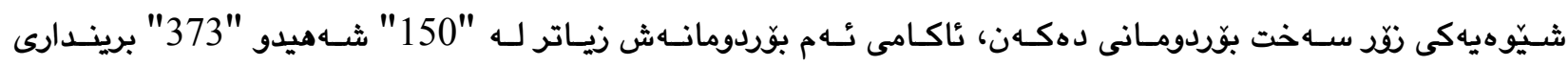

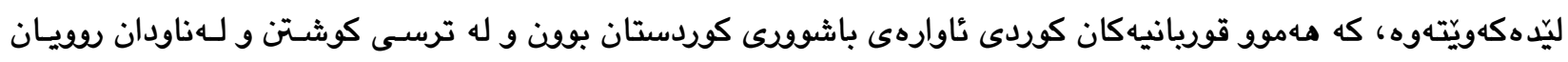
كردبوه ئهوىَ.

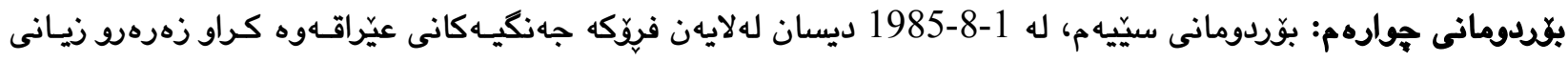
نَّرى بهدواى خوّيدا هيّنا.

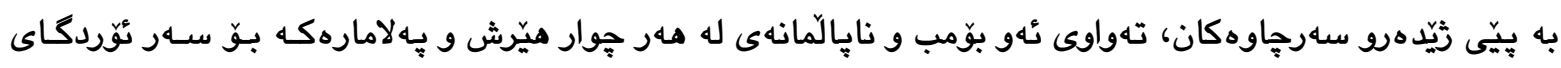

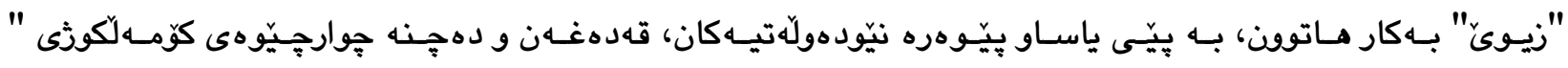
جينوّسايد"هوهـ

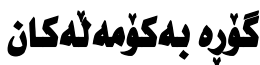

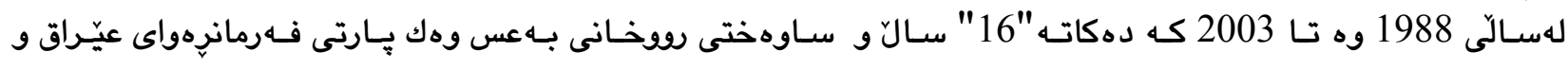

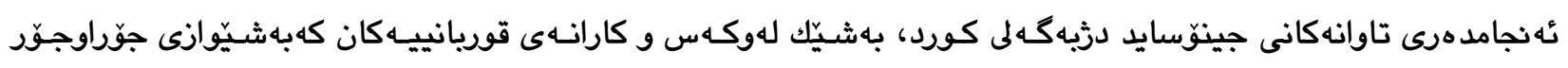

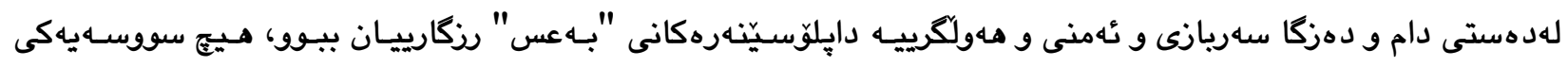

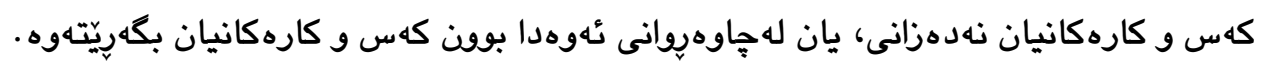




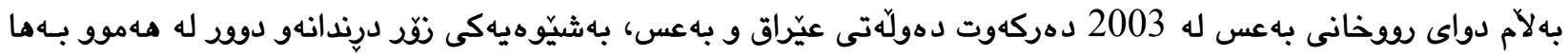

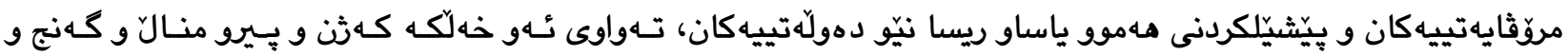

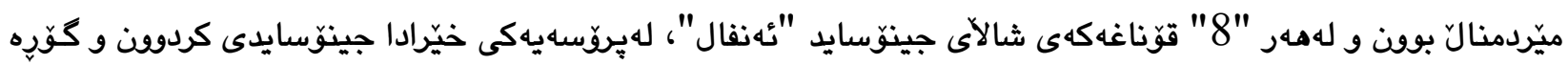

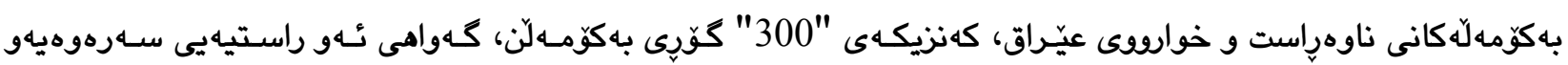

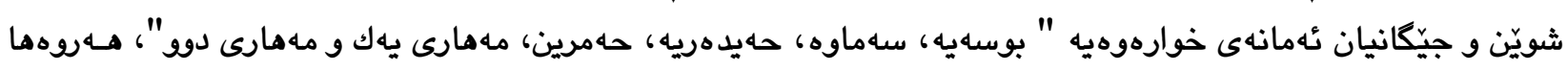
جهندين جيّكاو شوينيى تر.

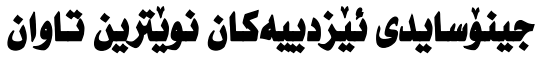

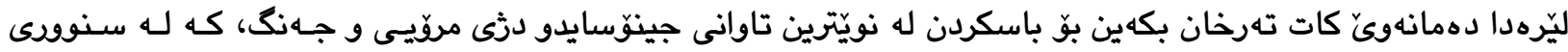

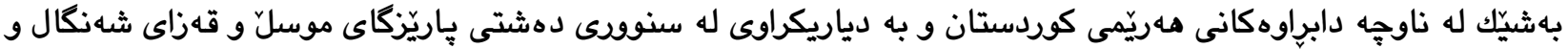

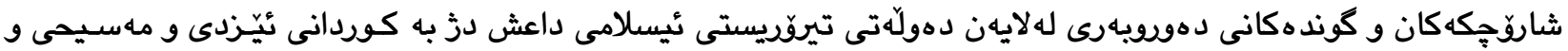

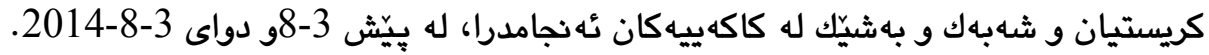
بهوردبونهوهو سهرنجدان، وهك بهره نجاميّك دهگهينه ئهو راستيهى كه له 3-8-2014 لهدواى هيّرشى تيوّرستان بـو

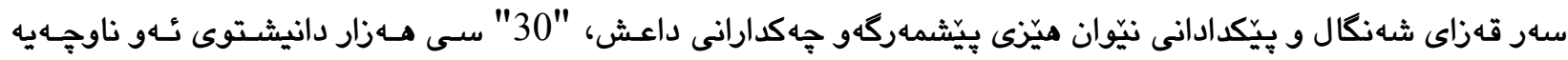

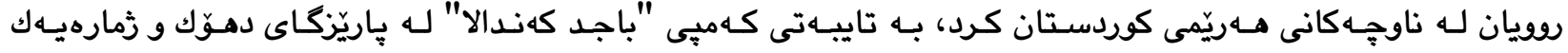

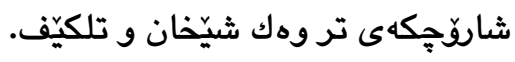

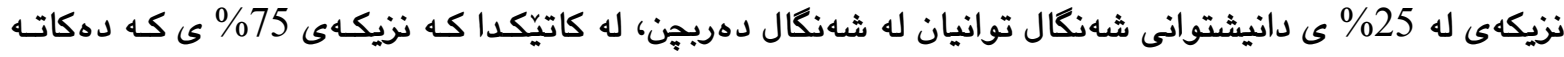

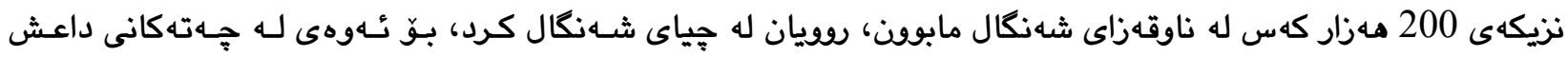

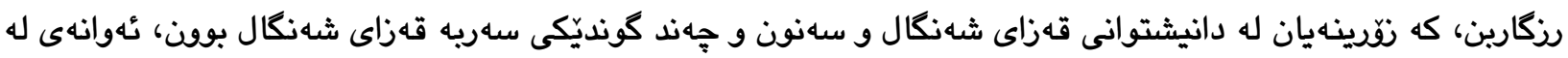

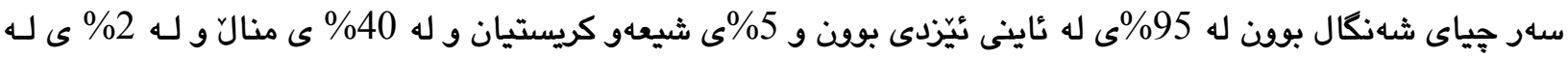

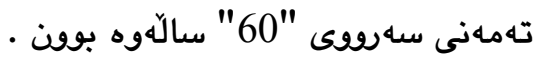

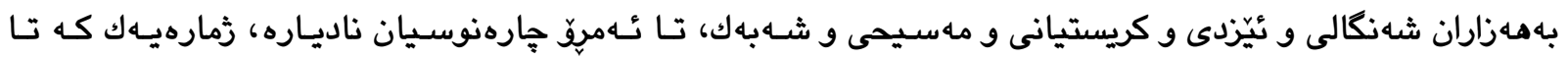

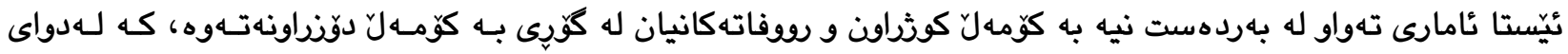

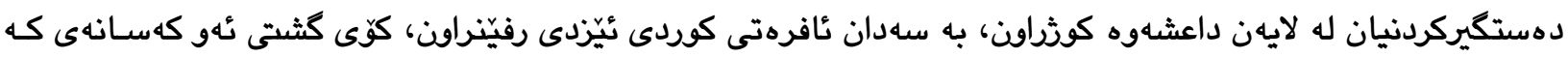

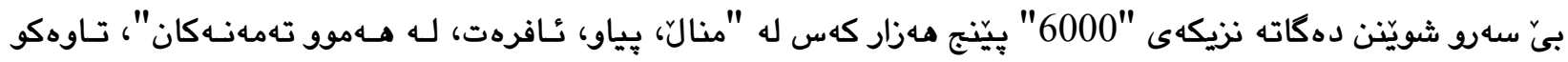

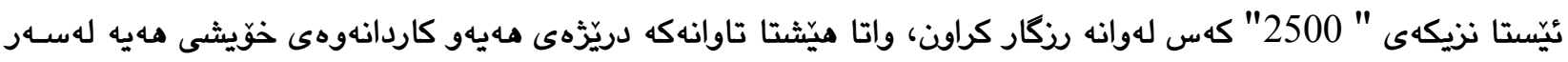
مهدوو ئاسته كان.

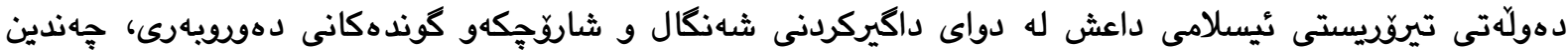
تاوانيان ئه نجاماوه، كه دهتوانين به م شيّوهيهى خوارهوه يِوليَنيان بكهين:

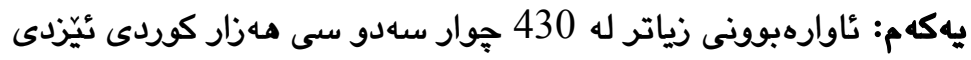

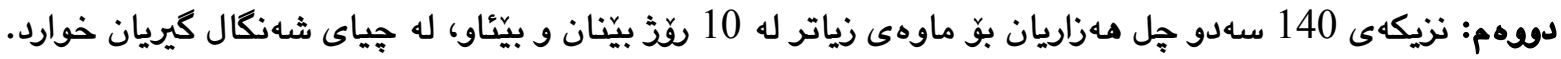
سيّيهم: نزيكهى 290 دووسهدو نهوهد مهزاريان ناوارهى هـريّمى كوردستان و توركياو سوريا بوون. 


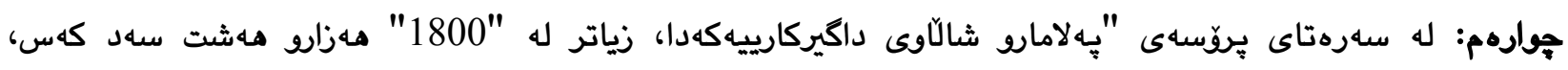

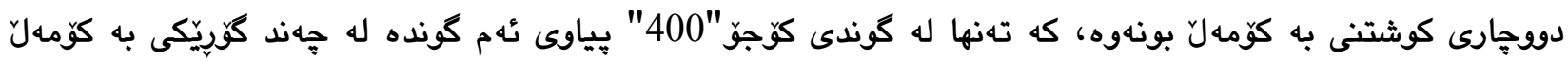

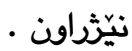

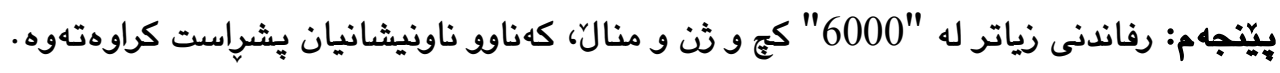

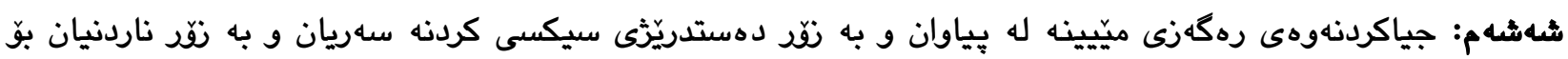
شوينانى ترى زَيْر دهلَّاتيان

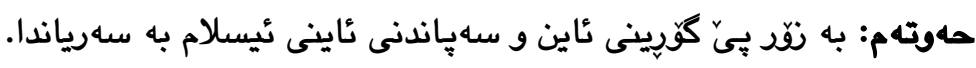

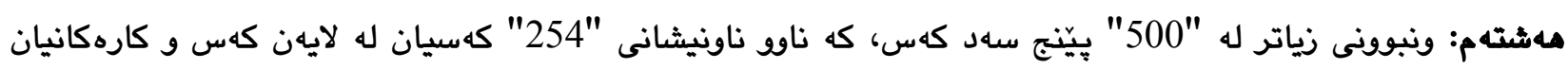

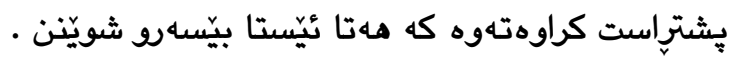

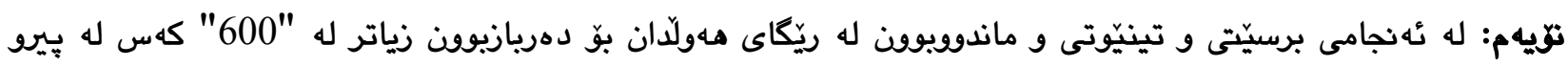

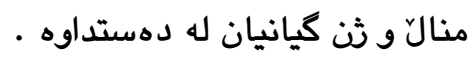

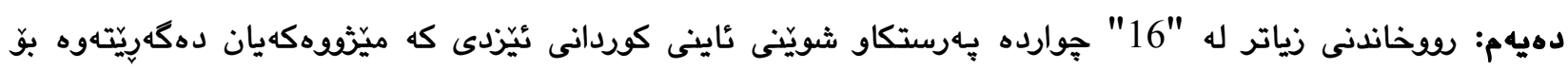

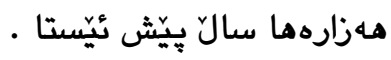

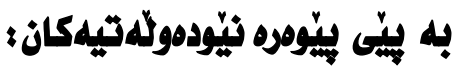

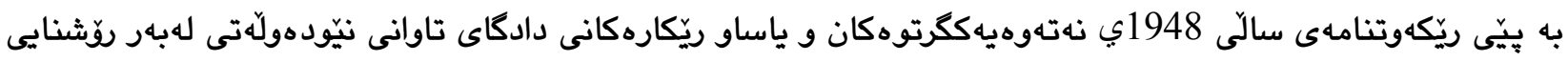
ريّككهوتنامهى روّماى 1998ئُة تاوانانهى كهلهرابودوو له لايهن دهولَّهى عيّراق و بهاعس و نويّترين تاوانيش لهلايهن داعش

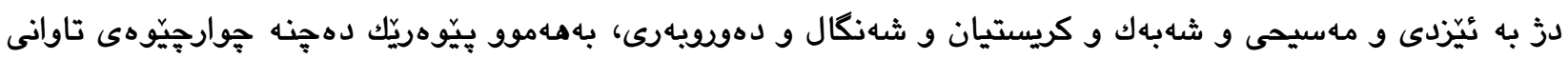

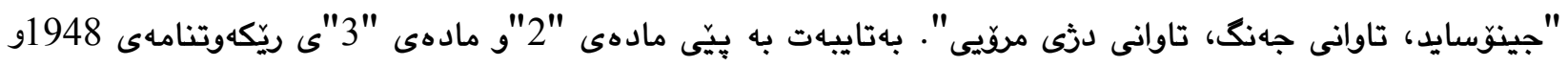

مادهى "5، 6، 7، 8"ى ريّكهوتينامهى روّما.

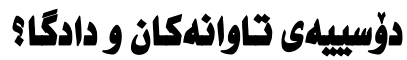

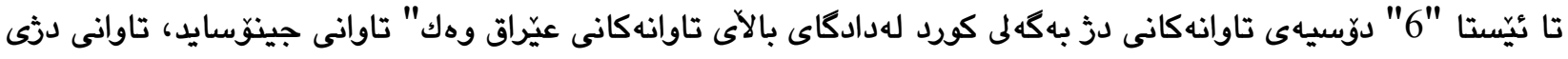

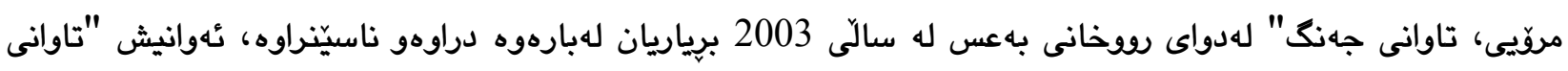
ئهنفال، تاوانى جينوّسايدى فهيليهكان، تاوانى جينوّايدى بهرزانيهكان، تاوانى جينوسايدى بهرزانيهكان، تاوانى جينوّسايدى قه لادزىّ، تاوانى جينوّسايدى شارى سهيدسادق"ن. ئهوانى تر، دوّسييهكانيان له "دادكاى بالآى تاوانهكانى

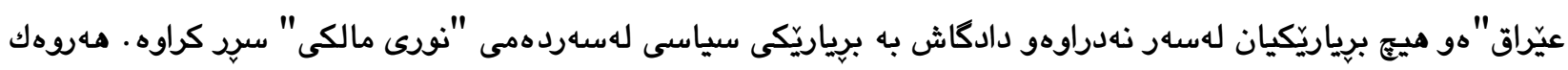

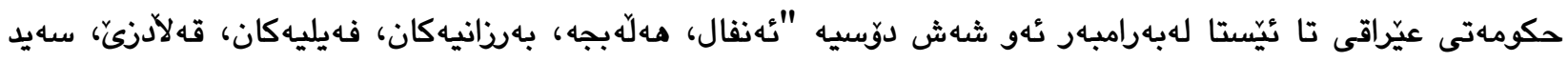
سادق" كه دادكا وهك تاوانى "جهنگ، دزَى مروّيى، جينوّسايد" له بهر روّشنايى ياساى دادكاى بالأى تاوانهكانى عيّرق،

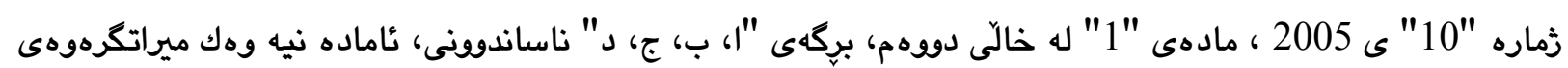

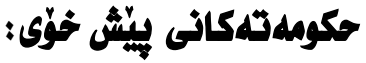

يهكهم: بهفهرمى داوايى ليّبوردن له گهلى كوردو يِيّكهاتهكانى بكات، لهبهرامبهر تاوانهكانى كه لهدثى ئهنجام دراوه. 
دوههم: بهههمان شيّوه حكومهى عيّراق ئاماده نيه، قهربووى زيان ليّكهوتوانى جوارجيّوهى تاوانهان بكاتهوه، كه

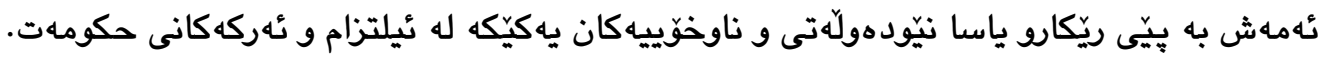

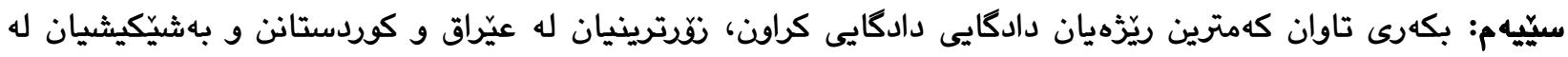

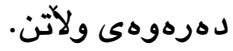

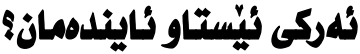

ئيّمه ئهركيّكى كهورهمان له ئيستاو ئاينده لهسهرشانه، بوّيه ههولّى ئهوه دهدهم بهم شيّوهيهى خوارهوه ريّ و

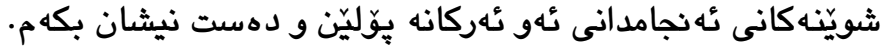

\section{لالهسلهرئاستى عيّراق}

1.فشار خسته سهر حكومهتى عيّراقى بهقهربووكردنهوهى زيانليككواتون و كهس و كارى قوربانيانى "تاوانى جينّسايد،

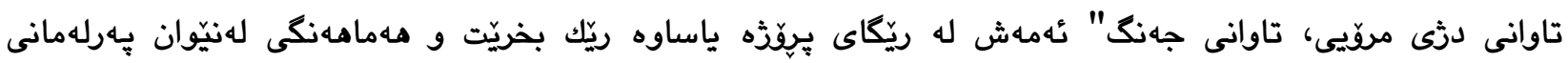

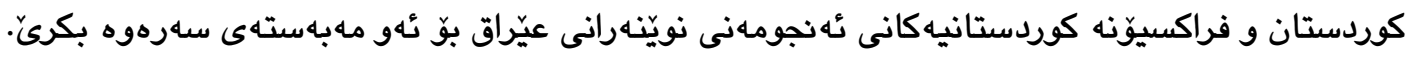

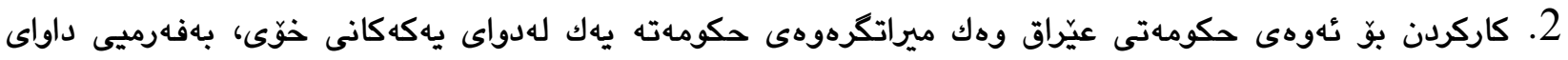
ليّبوردن لهكهلى كوردستان بكات لهبهرامبهر جينوّايدو تاوانه جياجياكان كهبهرامبهر كَلى كوردستان له لايهن حكومهتهكانى بِيّش خوّى ئهن نجام دراوه.

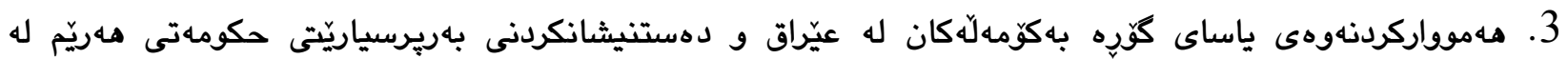

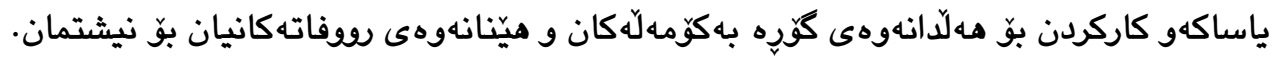

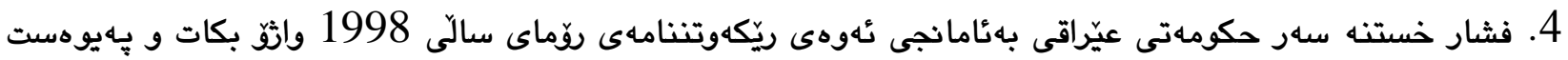

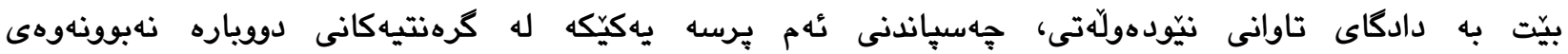
جينوسايدكردنهوهى كهله لهكمان.

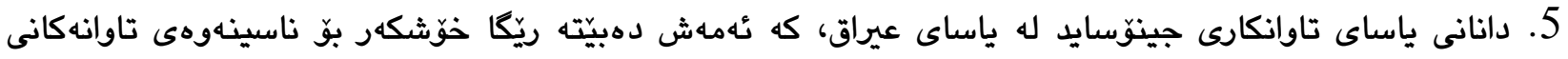
جينوّسايد دز بهكه لهكهان و جهه بِّاندنيان.

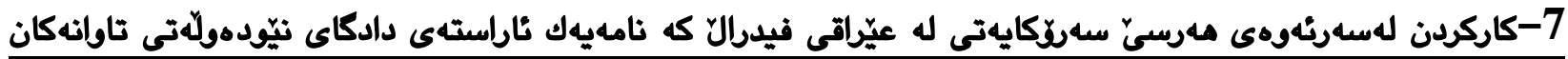

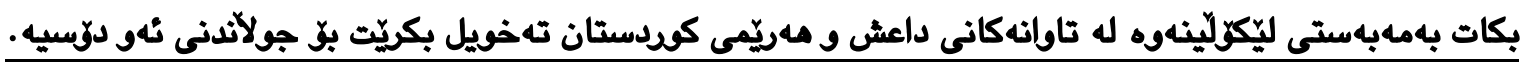

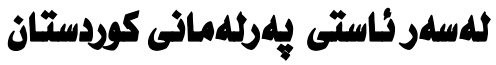

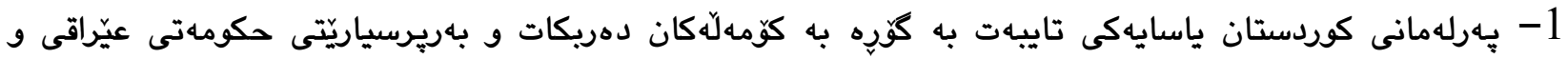

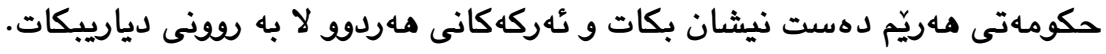

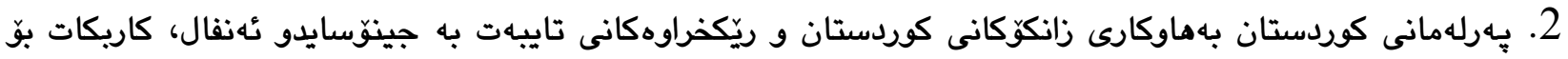

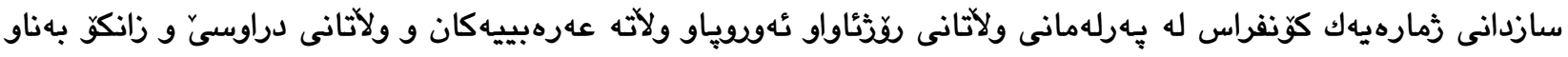
بانكهان، بوّ ناساندنى تاوانهانى جينوّسايد دزّ به كهلى كوردو كوردستان. 
3. پِهرلهمانى كوردستان بهفهرمى كوّمهلكوذى ئهرمهنهان لهلايهن دهولّهتى عوسمانيى به جينوّسايد بناسينىّ، كه

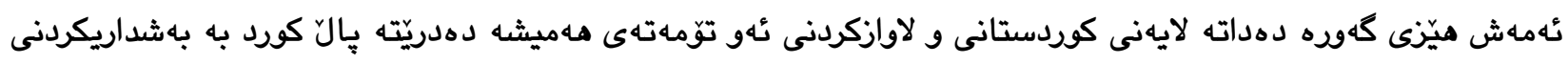
له جينوّسايدى نهارمهنه كان.

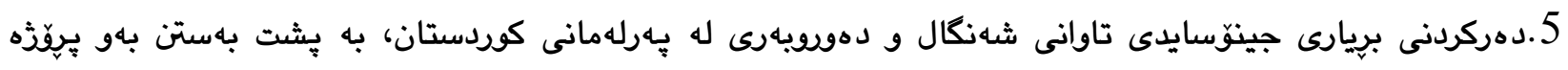

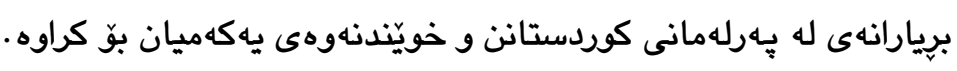

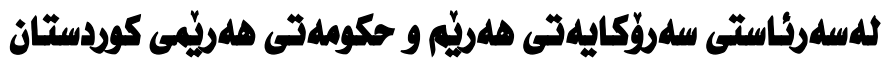

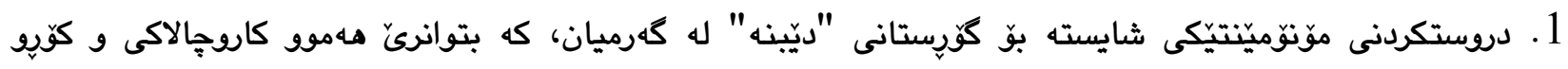

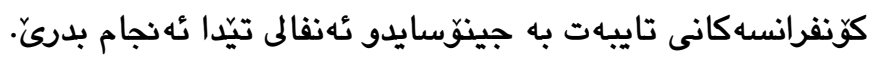

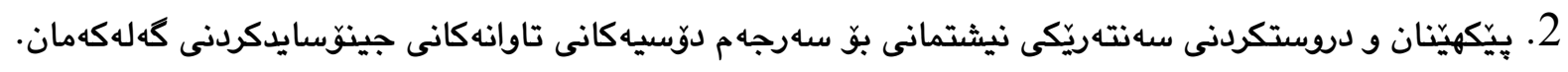

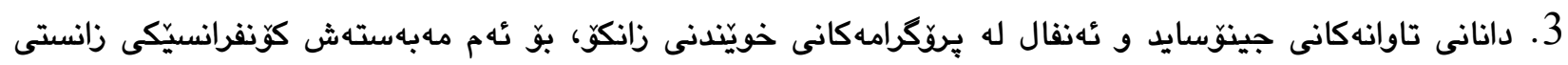

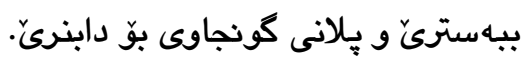

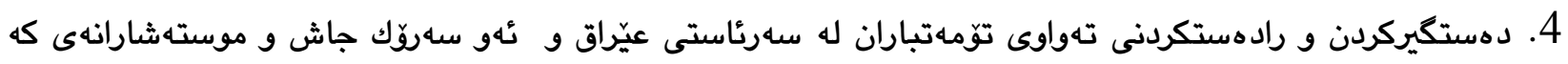

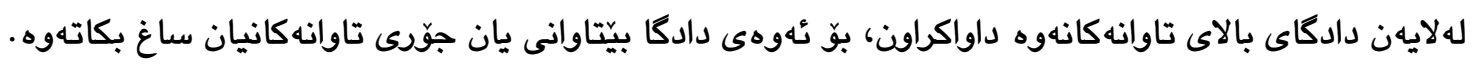

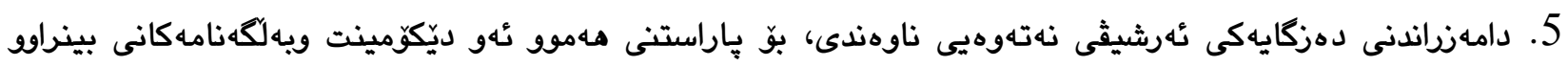

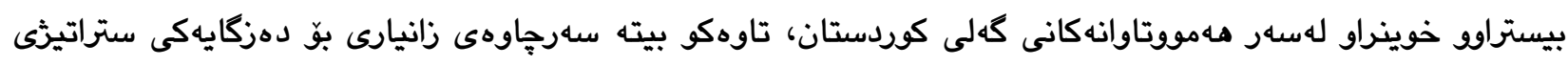

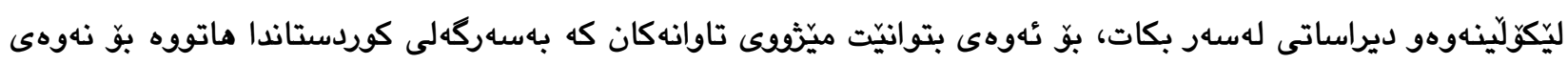

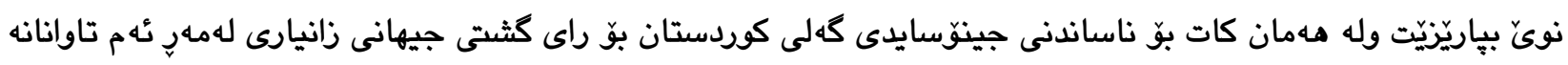
كوّيكاتهوهو به ديكوّمينتيان بكات .

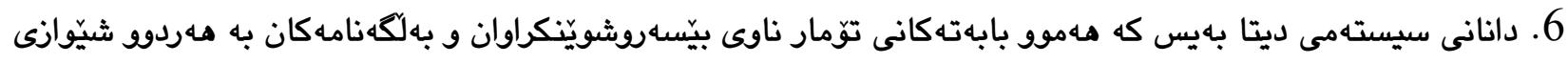

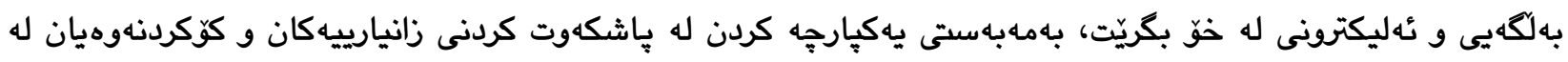

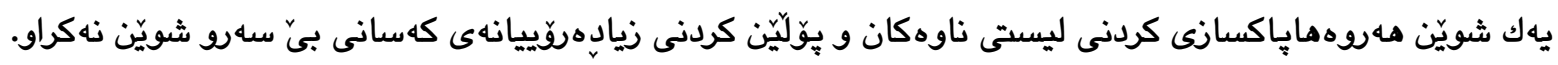

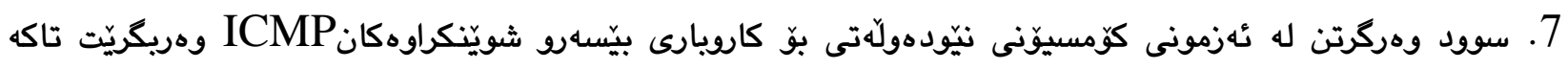
ريّكخراوى نيّودهولّهتيهبه تاييهتى له بوارى دوّسيّى بيّسهرو شويّنكراوهكان كاردهكات.

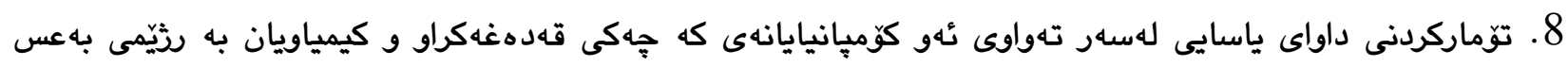

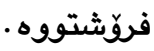

9. وهركيِرانى كتيّب و ديكوّمينتهكانى تايبهت به جينوّسايد و ئهنفال به زمانه زيندووهكانى دونيا، بهشيّوهيهى سيسته ماتيك و يِلان بوّدانراوله لايهن دهزكاكانى وهزارهتى روّشنبيرى و لايهنه يـهيوهنديدارهكان.

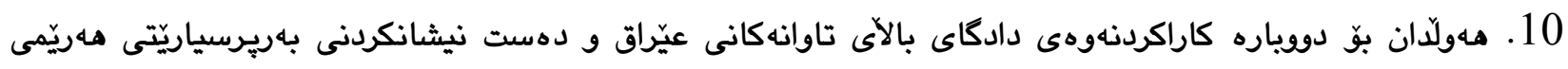
كوردستان له مهلَّوراندنى كارويارهكانى دادكا.

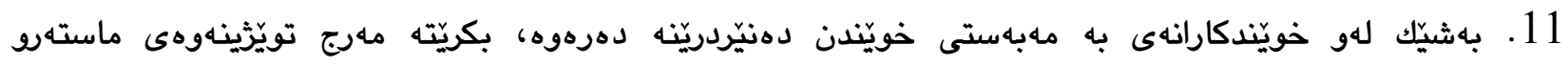
دكتوراكانيان، له سهرتاوانهكانى جينّوسايدو ئهنفال و كيميابارانى كهلهكهان بهو زمانانهى بِيّى دهخويِنن بيّت. 


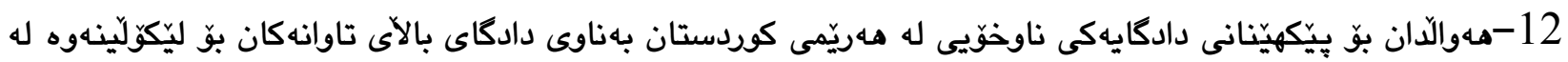
دوّسيهكانى تاوانى جينوّسايد.

13. عهدالهتى تئتقالى تاكه ريّكَهيه بوّ دابينكردنى داديهروهرى و قهرهبوكردنهوهى قوريانيهكان، بهبيّ عهدالهتى

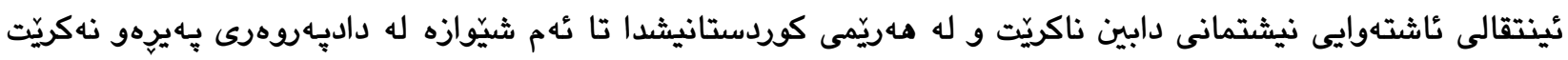
برينى تاوانى جينوّسايدى فهيليهكان و جينوّايدى بهرزانيهكان و جينوّسايدى ئهنفال و شنكال و برينهكانى ديكه ساريّز نابن و ئهكَرى دوياره بونهوه و رشتنى خويّنى زياتر له نارادا دهبىّ.

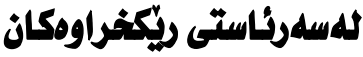

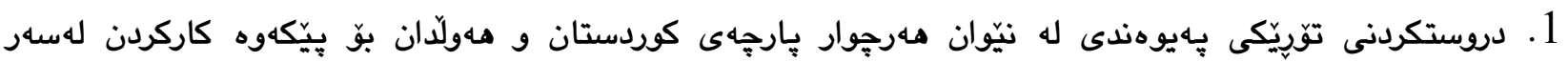

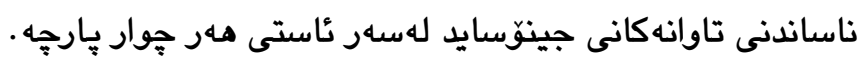
2. سود وهركرتن له ئهزمونى كاركردنى ريكخراوه جيهانيهكانى تايبهت بهجينوّسايدو دروستكردنى يِرديّكى توكمهى

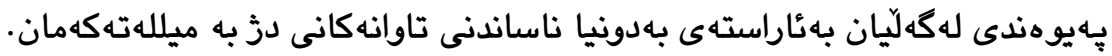

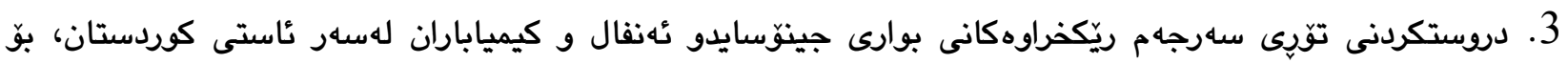
ئهوهى يهك كووتارى ناراستهكراومان مهبيت لهكاركردن لهسهر ئاستى ناوخوّو دهرهوهى كوردستان و به فهرمى

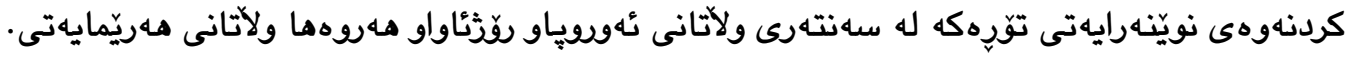

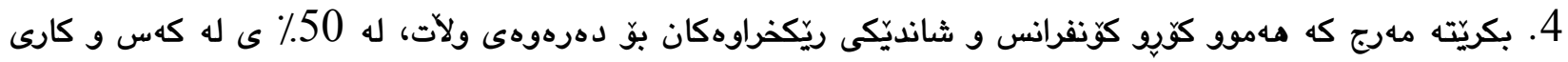
قوربانيهكان بن وهك بههيْزترين شايه تحالّى تاوانهكانى جينّوسايدو ئهنفال و كيمياباران.

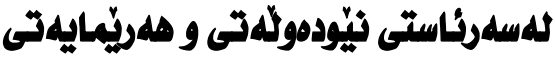

يهكهم: بهستنى كوّنفرانسى زانستى و نُكايمى، تايبهت به جينوّايدو ئهنفال، ئامانجى ئهم كوّنفرانسانه تايبهت به هدولّدان بوّ ناساندنى جينوّسايدو ئهنفال.

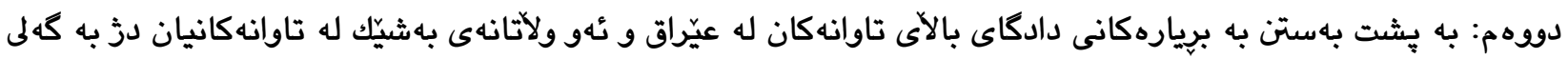

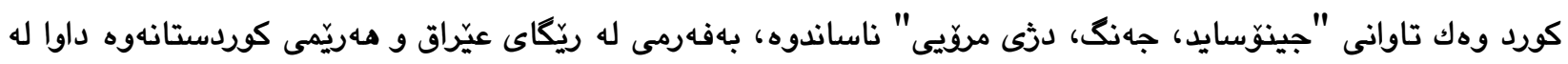

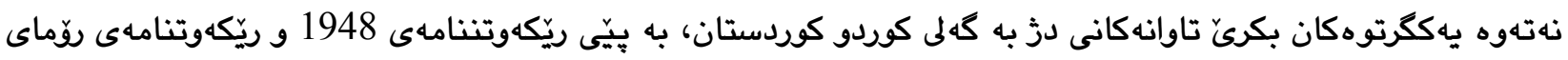
1998 بناسينّىْ

سيّيه م: كار لهسهر ئهوهبكريّ، ماوشيِوهى تاوانى جينّوسايدى ئيَزدييهكان تاوانهانى ترى وهك "عنهنفال، كيميابارانى

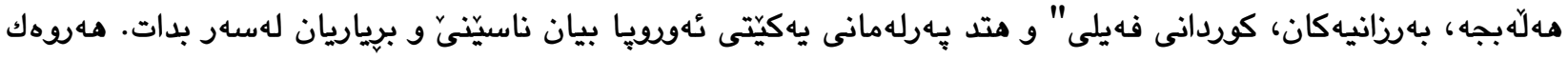

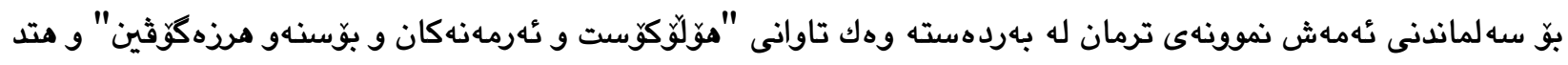

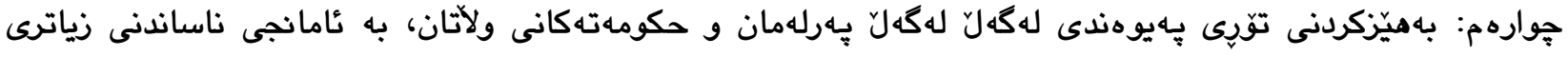

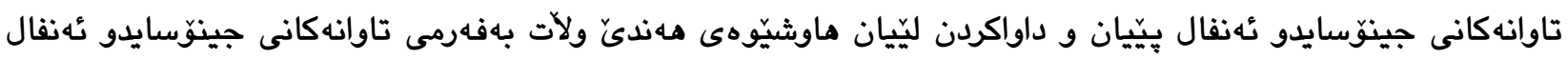
بناسن. 


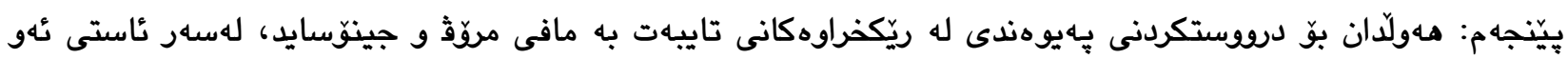
ولآتانهى بوونيان ههيه، ئهمهش وهك دهرفهتيّك بوّ ناساندنى تاوانهكان دز به كه لهكهمان.

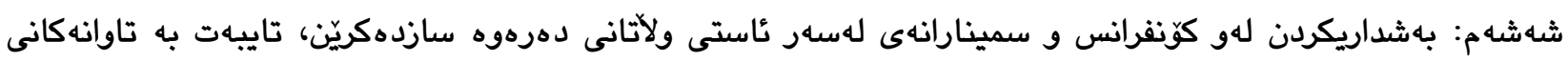

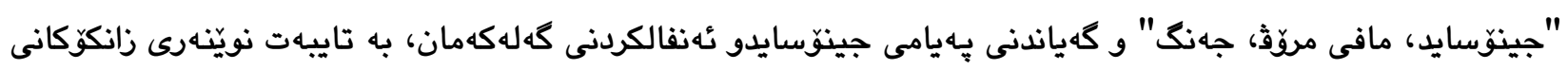
كوردستان و ريّكخراوهكانى تايبهت بهم بواره .

\section{سله رجاومكان:}

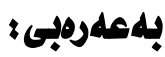

ـاحمد ناصر الفيلي، الكورد الفيليون "الأصالة التاريخية، ولمواطنة المهدورة"اكة 2013 ، بغداد -د، مونيرة اميد، المقابر الجماعية للكورد الفيلين،

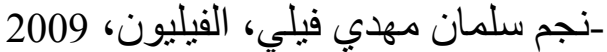

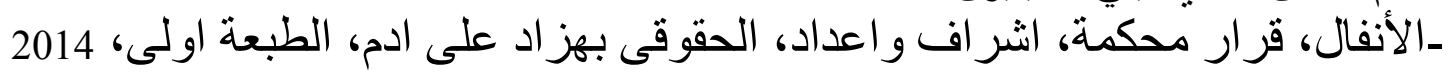

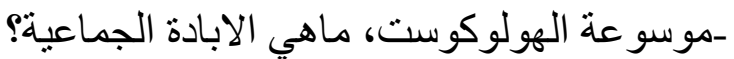
-

\section{بل بكوردى:}

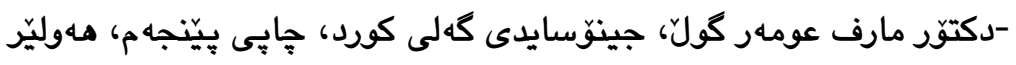

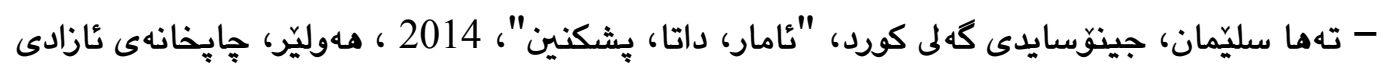
- دهرسيم ديبه كهيى، ئينيسكويِيدياى تاوانهكانى نهنفال و كوردوّسايدكردنى كهلى باشوورى كوردستان، 2010

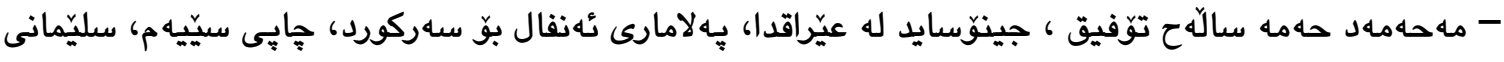
- عومهر مهحهمهد، يه لاماره سهريازييهكانى ئهنفال له مهشت قوّناغدا، جايّى يهكه م 2013

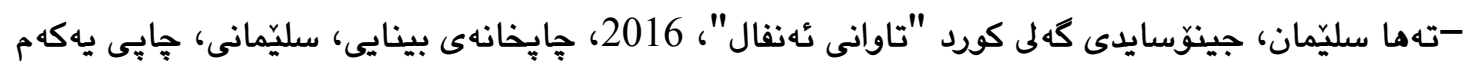

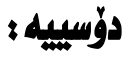

-دوّسيهى بهلكَهامهكانى جينوّسايدى كوردانى فهيلى له دادكاى بالآى تاوانهكانى عيّراق "بهلَّكهامهى نوسراوى بهعس،

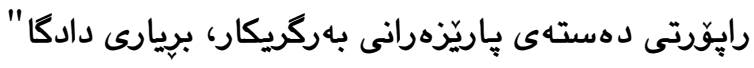

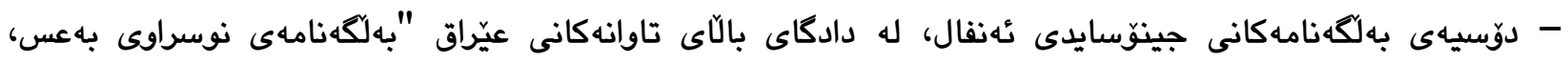

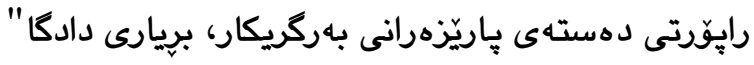

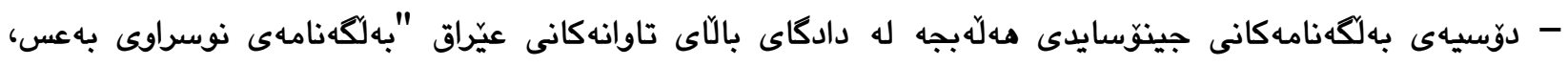

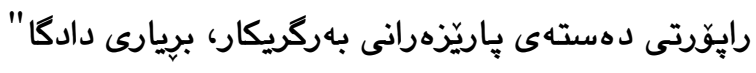

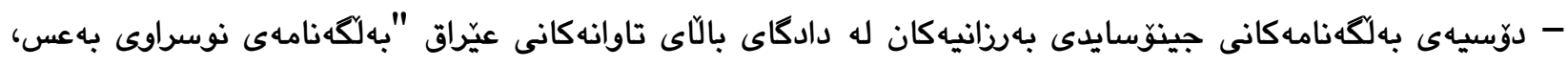

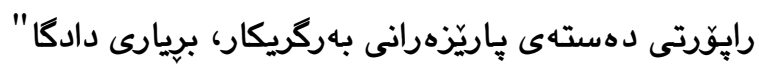

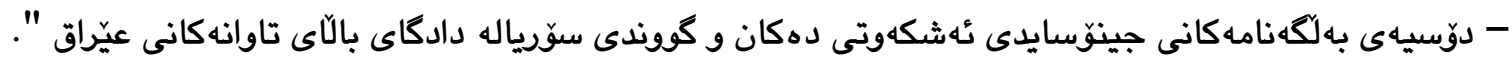
- دوّسيهى به لكَهامهكانى جينوّسايدى قهلادزيّ و سهيدساق له دادكاى بالّاى تاوانهكانى عيّراق. 